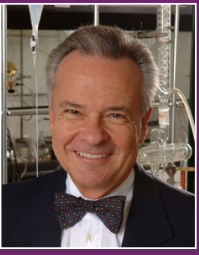

Professor George R. Newkome received his B.S. and Ph.D. in Chemistry from Ken State University. He was a postdoctoral fellow at Princeton University before joining Louisiana State University where he became a full professor in 1978 and then LSU Distinguishe and then LsU Ding joined the University of South Florida in Tampa as their first Vice President for Research with a faculty appointment in chemistry. He was later named Distinguished Research Professo in 1992. In 2001, he became Vice President for Research and Dean of the Graduate School at The University of Akron. He Dean of the Graduate School at The University of Akron. He is the Oelschlager Professor of Science and Technology and professor in the departments of Polymer Science and Chemistry. Currently, he is the President and CEO of the University of Akron Research Foundation and the Akron Innovation Campus as well as a Fellow of the American Association for the Advancement of Science, member of the Royal Society of Chemistry, Fellow of Science, me the American $A s s c$ ation for the Advancement of the National Academy of Inventors, and on the board of director for 14 corporations as well as numerous editorial boards. He has published over 450 papers, 50 issued and international patents, and edited/written over 15 scientific books and monographs. His technology transfer team has spun-out over 100 companies from within their communities.

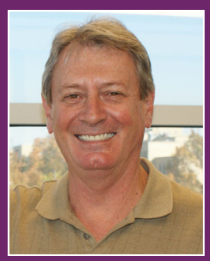

Charles N. Moorefield currently is a Senior Research Scientist within The Maurice Morton Institute for Polyme Science at The University of Akron, Akron, $\mathrm{OH}$. $\mathrm{He}$ Akron, OH. He received his $P$. D. in The University of South Florida, Tampa, FL. His graduate research led to the first $1 \rightarrow 3 \mathrm{C}$-branched, unimolecula micelle possessing an all-saturated hydrocarbon framework based on dendritic construction techniques. Since then, he has authored or co-authored over 90 scientific articles and communications 30 U.S. and International patents, and over 12 reviews and book chapters concerning dendritic and metallomacrocyclic architectures.

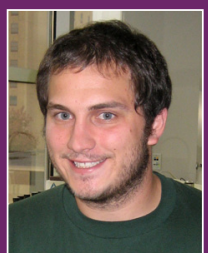

Anthony Schultz was born in Alpena, Michigan (USA) and obtained his B.S. degree in 2007 from Grand Valley State University. He moved to Akron, OH (USA) in 2007 and began working unde Dr. George Newkome at The University of Akron. He completed his Ph.D. degree of the selfassembly ofterpyrdine-based on the self-assembly of terpyridine-based architectures in 2012. He currently works in Dr. Newkome's group as a postdoctoral research associate and has

accepted a position at The 3M Company.

\title{
From dendrimers to fractal polymers and beyond
}

\author{
Charles N. Moorefield ${ }^{1}$, Anthony Schultz ${ }^{2}$, \\ George R. Newkome ${ }^{1-3, *}$
}

\author{
${ }^{1}$ The Maurice Morton Institute for Polymer Science, \\ ${ }^{2}$ The Department of Chemistry, and \\ ${ }^{3}$ The Department of Polymer Science, The University of Akron,
}

Akron, OH, 44325, USA

The advent of dendritic chemistry has facilitated materials research by allowing precise control of functional component placement in macromolecular architecture. The iterative synthetic protocols used for dendrimer construction were developed based on the desire to craft highly branched, high molecular weight, molecules with exact mass and tailored functionality. Arborols, inspired by trees and precursors of the utilitarian macromolecules known as dendrimers today, were the first examples to employ predesigned, $1 \rightarrow 3$ $C$-branched, building blocks; physical characteristics of the arborols, including their globular shapes, excellent solubilities, and demonstrated aggregation, combined to reveal the inherent supramolecular potential (e.g., the unimolecular micelle) of these unique species. The architecture that is a characteristic of dendritic materials also exhibits fractal qualities based on self-similar, repetitive, branched frameworks. Thus, the fractal design and supramolecular aspects of these constructs are suggestive of a larger field of fractal materials that incorporates repeating geometries and are derived by complementary building block recognition and assembly. Use of terpyridine- $\mathrm{M}^{2+}$-terpyridine (where, $\mathrm{M}=\mathrm{Ru}, \mathrm{Zn}, \mathrm{Fe}$, etc) connectivity in concert with mathematical algorithms, such as forms the basis for the Seirpinski gasket, has allowed the beginning exploration of fractal materials construction. The propensity of the fractal molecules to self-assemble into higher order architectures adds another dimension to this new arena of materials and composite construction.

Uniterms: Arborol. Dendrimer. Supramolecular. Terpyridine. Self-assembly.

O advento da química dendrítica tem facilitado a pesquisa de materiais por permitir o controle preciso do posicionamento do componente funcional na arquitetura macromolecular. Os protocolos sintéticos iterativos usados para construção dos dendrímeros foram desenvolvidos baseados no desejo de elaborar moléculas extremamente ramificadas, com alta massa molecular, massa exata e funcionalidade planejada. Arborols, inspirados em árvores e precursores de macromoléculas utilitárias, conhecidas hoje como dendrímeros, foram os primeiros exemplos a empregar blocos de construção de ramificação-C $1 \rightarrow 3$; Características físicas dos Arborols, incluindo a sua forma globular, excelente solubilidade, e agregação, combinam-se para revelar o potencial supramolecular inerente (isto é, a micela unimolecular) destas espécies únicas. A arquitetura que é característica dos materiais dendríticos também exibe qualidades fractais com base em estruturas repetitivas, ramificadas e auto-similares. Assim, o design fractal e os aspectos supramoleculares destas construções são sugestivas de um campo maior de materiais fractais que incorporam geometrias repetidas. $\mathrm{O}$ uso de terpiridina- $\mathrm{M}^{2+}$-terpiridina (onde, $\mathrm{M}=\mathrm{Ru}, \mathrm{Zn}, \mathrm{Fe}$, etc) em conjunto com algoritmos matemáticos tais como as formas da base do Triângulo de Seirpinski, tem permitido o início da exploração da construção de materiais fractais. A propensão da auto-criação de moléculas fractais para arquiteturas de ordem superior adiciona outra dimensão para essa nova arena de materiais e construção de compostos.

Unitermos: Arborol. Dendrímero. Supramolecular. Terpiridina. Auto-montagem.

*Correspondence: George R. Newkome. The University of Akron, 170 University Circle - RM501B - Akron, Oh - USA. E-mail: newkome@uakron.edu 


\section{INTRODUCTION}

Building block architectures are dependent on the physical and chemical properties of the desired material under construction; although at times, the properties of the new materials are not readily apparent based solely on the building block(s) design. This leads to an evolution in materials' synthesis and utility, as well as an element of excitement and anticipation with regard to the discovery of unknown local and aggregate attributes. Such has been the paradigm of a class of polymers known as dendrimers (Newkome et al., 2001; Newkome, Shreiner, 2010; Moorefield et al., 2012).

From their first published reports in 1985, dendrimers and dendritic materials, characterized by a regularly repeating, branched motif that may be simply described as tree-like, have captured the attention of research groups around the globe. This is due in-part to several factors, including the potential to integrate the dendritic constructs with other materials in order to instill the desired physical or structural properties. This generates a tailored molecular assembly possessing enhanced physical and/or structural characteristics for a utilitarian outcome. For example, high molecular weight species can easily be made soluble in aqueous or non-aqueous media, based on the incorporated functionality (Yu et al., 2013). As well, and perhaps most importantly, with the advent of dendritic synthetic strategies, chemists now have better insight to incorporate precise control over the placement of all the components of macromolecular materials that could be fully and unequivocally characterized.

Dendrimers can be envisioned (Figure 1) by considering a core possessing multiple arms, where each arm or branch is subsequently connected to a preconstructed branched building block (or dendron, adopted from the synthon terminology) giving rise to an initial layer or generation. Repetition of the building block layering produces the next higher generation dendrimer. Continued elaboration produces higher generations. Starting with a core possessing 4 arms and using a $1 \rightarrow 3$ branched dendron will ideally afford dendrimers possessing $12,36,108,324$, and 972 termini or surface groups for generations $1,2,3,4$, and 5 , respectively. Design aspects of dendrimers or dendrons encompass branching centers (e.g., $\mathrm{C}, \mathrm{N}$, aryl, etc.), arm length and rigidity (e.g., aryl, acetylenic, alkyl, etc.), terminal moiety $\left(\mathrm{CO}_{2} \mathrm{H}, \mathrm{NH}_{2}, \mathrm{OH}\right.$, etc. $)$. These parameters combine to influence the ultimate utilitarian physical properties, such as: void volume, internal hydrophobicity/lipophilicity, dielectric potential, and porosity, to mention but a few.

Notably, dendrimer construction has been conceived and developed in many variations. Building from the

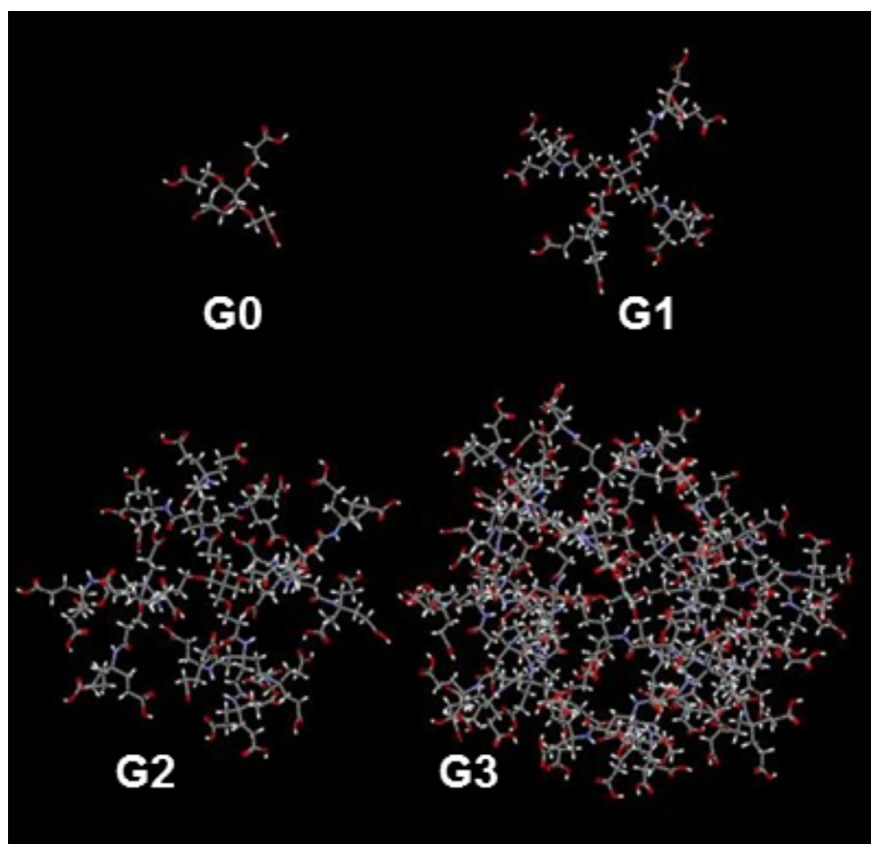

FIGURE 1 - Computer generated images of generations 0 through 3 of a $1 \rightarrow 3 C$-branched, dendrimer.

outside inward complements construction from the inside outward (convergent vs. divergent protocols). Dendron attachment has been effected using a wide variety of covalent and non-covalent protocols. As well, dendrimers can be constructed using linear building blocks, where branching centers are created during generational growth. Dendrimers have been examined in a numerous applications, including chemical (Kumar et al., 2008; Park et al., 2009) and electrical sensing, (Koo et al., 2001) micellar host-guest ability (Boisselier et al., 2010), coatings and polymer additives (Hartmann-Thompson et al., 2009), and drug delivery vehicles (Cheng et al., 2011).

Dendrimers have further been demonstrated to be examples of molecular fractals (Mandelbrot, 1982; Farin, Avnir, 1991; Cho et al., 2006) based on their repeating architectural motif at differing size scales. It is the fractal quality of the dendrimer that has given rise to new types of material in our laboratories that we have coined - fractal polymers.

As witnessed over the past 50 years, chaos science has introduced us to a methodology that permits us to observe order and patterns that were noted earlier as the simply the complexity in nature. Thus, the elements of chaos, fractals and dynamics have been introduced to mathematically address the complexity of nature (Peitgen et al., 2004). Notably, dendrimers are but a small avenue in the world of fractals. Molecular architectures exhibit self-similarity on differing scales that allow incorporation of a balance of interrelated attributes and structural compo- 
nents that are ideally suited for interdependent component positioning. Towards these directions, we are working to design and assemble nanoscale homo- and heteronuclear materials possessing a non-branched morphology in which metal center incorporation and the structural architecture join with supramolecular concepts to facilitate material applications. The use of ligand-metal-ligand connectivity has thus served to expand our directed and self-assembly work into the novel, utilitarian "fractal" macro- and nanomolecular architecture arena (Newkome et al., 2006).

A fractal polymer with the attributes of a Sierpinski triangle can be envisioned geometrically by considering the transformation upon proceeding from a 3-directional, $2 \mathrm{D}$ dendrimer to a triangular, $1 \rightarrow 3$ branched motif that can be overlaid onto a Sierpinski gasket design, which was mathematically envisioned in 1916. The dendritic branches bisect the collective triangle sides' at all midway points; way points; and hence, form the basis for the construction of a Sierpinski triangle (Figure 2).

The use of ligand-metal-ligand connectivity in these constructs is anticipated to lead to the development of materials with demonstrated potential as energy storage and release devices, based on stable oxidized and reduced metal states, as components of molecular devices, such as in new photovoltaic cells and organic light emitting diodes (OLEDs), based on their photo- and electroluminescence properties (Chen et al., 2010) and as molecular switches and optical display components (Yoon et al., 2010) based on their low spin-high spin characteristics. These attributes coupled with the potential to self-assemble the fractal materials into nanotube and nanofiber structures make them ideal candidates for bio-pharma applications. This review is intended to give a brief overview of past and on-going work, in our laboratories, as well as introduce the reader the the molecular world via traditional mathematics and the beauty of Mother Nature's fractal patterns that are all around each of us.

\section{EARLY WORK}

Initial work in our laboratories (1982-1985) resulted in the first example of a one-directional, $1 \rightarrow 3 C$-branched dendrimer (Newkome et al., 1985) (1, Figure 3), that was described as an arborol for its likeness to tree architecture. Inspiration for the terminology and the molecular architecture was derived from the Leeuwenberg model for a tree, (Hallé et al., 1982; Tomlinson1983) which branched $1 \rightarrow 3$ where the branch juncture was suggestive of a tetrahedral, tetravalent carbon. The critical building blocks chosen to facilitate the construction of the $1 \rightarrow 3$ branched motif included triethyl methanetricarboxylate (Newkome, Baker, 1986) that could be easily attached to an alkyl halide by nucleophilic substitution and tris(hydroxymethyl)aminomethane, which would undergo facile amidation of the ester moieties. Each of these simple dendrons possessed the requisite tetrahedral carbon branching center to allow maximum branching in a carbon framework and notably the amide connectivity was highly stable and not prone to retro-reactions. Its spherical shape and aqueous solubility properties led to the suggestion in that paper that these highly branched structures would possess unimolecular micelle character.

This arborol was closely followed in time by the construction of another [9] alcohol-terminated arborol (Newkome et al., 1986b) using benzene as the core (2, where [9] denotes the number of hydroxyl groups at the arms ends). Its synthesis provided more insight into highly branched tree-like, architectures. Transmission electron micrograph images revealed globular microcrystalline regions, whereby molecular modeling calculations indi-
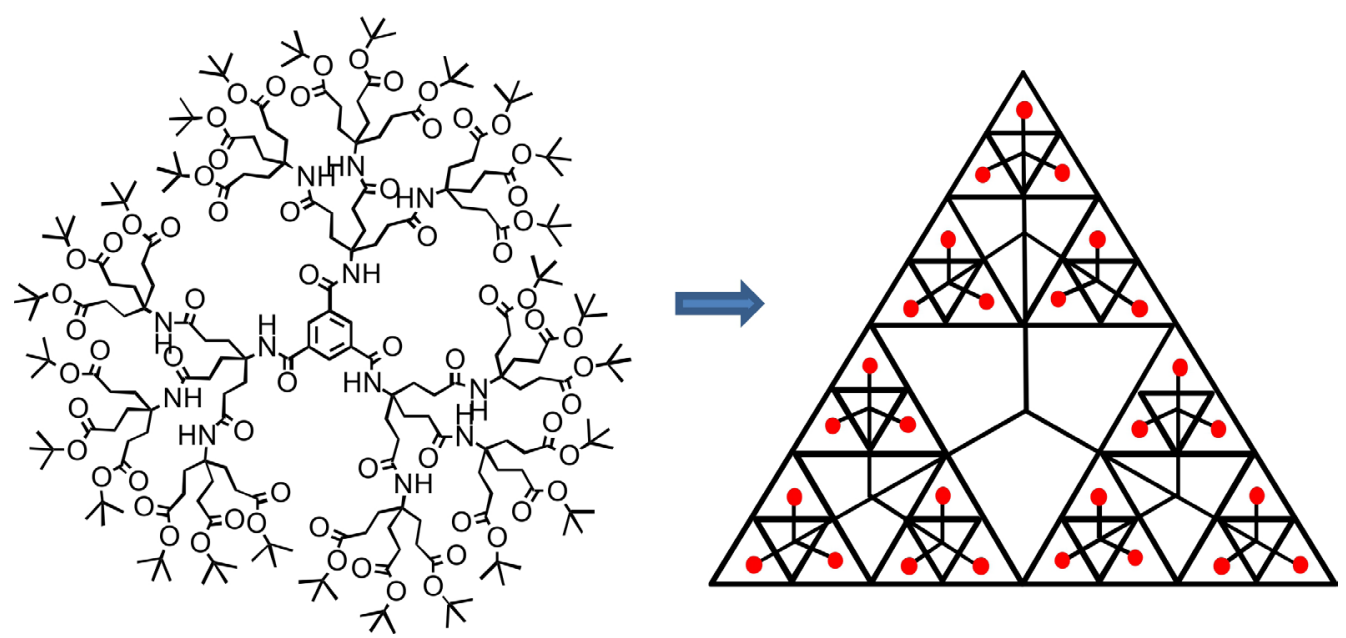

FIGURE 2 - Conceptual progression from branched dendrimer architecture to interrelated, non-tree-like fractal motifs. 
<smiles>CCCCCC(COCCC(C(=O)NC(CO)(CO)CO)(C(=O)NC(CO)(CO)CO)C(=O)NC(CO)(CO)CO)(COCCC(C(=O)NC(CO)(CO)CO)(C(=O)NC(CO)(CO)CO)C(=O)NC(CO)(CO)CO)C(=O)NC(CO)(CO)C(=O)NC(CO)(CO)CO</smiles><smiles>O=C(NC(CO)(CO)CO)C(Cc1cc(CC(C(=O)NC(CO)(CO)CO)(C(=O)NC(CO)(CO)CO)C(=O)NC(CO)(CO)CO)cc(CC(C(=O)NC(CO)(CO)CO)(C(=O)NC(CO)(CO)CO)C(=O)NC(CO)(CO)CO)c1)(C(=O)NC(CO)(CO)CO)C(=O)NC(CO)(CO)CO</smiles><smiles>O=C(NC(CO)(CO)CO)C(CCCCCCCCCCC(C(=O)NC(CO)(CO)CO)(C(=O)NC(CO)(CO)CO)C(=O)NC(CO)(CO)CO)(C(=O)NC(CO)(CO)CO)C(=O)NC(CO)(CO)CO</smiles>

FIGURE 3 - Arborol architecture [Newkome, et al., J. Org. Chem., v.50, p.2003-2004, 1985; J. Am. Chem. Soc., v.108, p.849-850, 1986 - Reproduced by permission of The American Chemical Society; J. Chem. Soc., Chem. Commun., p.752-753, 1986 - Reproduced by permission of The Royal Society of Chemistry].

cated the $\sim 200 \AA$ diameter microcrystals were comprised of $c a .40$ molecules; subsequently, the potential for the arborols to aggregate revealed their micellar behavior and the potential for host-guest encapsulation, reinforcing our concept of unimolecular micellar properties. Light scattering experiments confirmed this behavior by revealing a $2.02 \mathrm{mM}$ critical micelle concentration.

Shortly after the [9] arborol report, a new class of arborol (3) was developed and communicated. The two-directional [9]- $n$-[9] and [6]- $n$-[6] arborol series (Newkome et al., 1986a; Newkome et al., 1990) that each formed aqueous gels at concentrations less than 2 wt \% (where [9] or [6] denote the number of end group hydroxyl moieties and $n$ denotes the number of methylene groups in the alkyl chain connecting the two hydroxylterminated, dendritic units). Access to these new arborols was achieved in two steps by reacting either the $\mathrm{Na}^{+}$salt of the methanetricarboxylate or malonate esters with an appropriate $\alpha, \omega$-dibromoalkane to give the corresponding nona- or hexa-esters, followed by treatment under basic conditions with the tris(hydroxylmethyl)aminomethane dendron to give the desired arborol series.

The gels derived from these two-directional dendritic constructs exhibited birefringence when viewed between cross-polarized and plane-polarized light filters indicative of extended ordered structure. This was confirmed by transmission electron microscopy (TEM) that revealed linear, fiber-like strands with diameters of $35 \AA$, which corresponded well with a calculated CPK length of $c a .30 \AA$. It was postulated that these dumbbell-like macro-molecules stacked in a perpendicular manner to produce the aggregates possessing lipophilic interiors and hydrophilic exteriors. Fluorescence of chlortetracycline in the presence of the gel provided support for the proposed aggregation based on the dyes dependence on a lipophilic environment for emission.

\section{UNIMOLECULAR MICELLES}

The unimolecular micelle concept came to fruition with the synthesis of a dendrimer possessing an allsaturated hydrocarbon framework termed a Micellenoic Acid (Newkome et al., 1991a; Newkome et al., 1991b) (4, Figure 4) - the first example of an alkyl-based unimolecular micelle. Key building blocks leading to its construction were accessed by employing a radical initiated nitro group substitution with acrylonitrile at a tertiary carbon. This provided a critical three carbon homologation of a functional group from the requisite quaternary branching center, thereby allowing for easy manipulation. Transformation of the newly incorporated nitrile group to a terminal alkyne provided for facile attachment of the building block to an alkyl halide. Employing an alkyl tetrabromide as the core and the $1 \rightarrow 3 C$-branched, monoalkyne trisbenzyl ether dendron allowed construction of the $1^{\text {st }}$ and 
$2^{\text {nd }}$ generation acid-terminated dendrimers by converting the surface groups to carboxylic acids via benzyl deprotection and subsequent hydroxyl oxidation.

Aggregation of the dendrimers in solution, promoted by carboxylic acid-based $H$-bonding, was prevented by ion exchange of the $\mathrm{Na}^{+}$salt to afford the tetraalkylammonium carboxylate. Confirmation of the exchange was evidenced in the electron micrographs of 4 that individually exhibited $30 \AA$ molecular diameters and that compared favorably to the calculated values (Newkome et al., 1991b).

Using diphenylhexatriene (DPH), as a molecular probe, fluorescence lifetime and anisotropy decay values observed in phase resolved anisotropy experiments corresponded well to that reported with DPH in phosphatidylcholine vesicles, thereby demonstrating the micellar hostguest relationship in an aqueous environment. Additional molecular probes used to explore the micellar properties of these dendrimers included chlortetracycline (fluorescence in a lipophilic environment), phenol blue, and naphthalene (UV absorbance and solubilization by the dendrimer in an aqueous medium), and pinacyanoyl chloride (color change in the dendritic lipophilic interior).

Another unique family of dendrimers $(e . g ., 5)$ (Young et al., 1994) that has been shown to possess micellar properties was derived from a novel aminotriester, commonly known as Behera's amine after the first person to synthesize it; prepared in two-steps starting with the treatment of $\mathrm{MeNO}_{2}$ with tert-butyl acrylate, followed be reduction of the nitro group to the amine). This dendron facilitates branched growth by peptide-type coupling to a carboxylic acid end group followed by removal of the tert-butyl moieties to generate new acid termini for continued elaboration. Dendrimers up to the $5^{\text {th }}$ generation, theoretically possessing 972 surface ester or acid functional groups, have been prepared using this amide-based, iterative technology.

Systematic evaluation of the effect of $\mathrm{pH}$ on their hydrodynamic radii using 2-dimensional, diffusion ordered ${ }^{1} \mathrm{H}$ NMR spectroscopy (DOSY NMR) revealed the carboxylic acid series to be largest, or in an expanded state, in neutral and basic $\mathrm{pH}$; whereas, the corresponding amine-terminated constructs exhibited contraction in basic media. Hydroxyl-terminated dendrimers exhibited a constant hydrodynamic radius over the range from basic to acidic $\mathrm{pH}$. Environmental effects can thus be employed as containment and release mechanisms for encapsulated drugs.

As well, the amide-based, acid-terminated dendrimers were shown to be useful as a micellar substitute in the analytical technique of electrokinetic capillary chromatography. (Kuzdzal et al., 1994, 1997) A series of
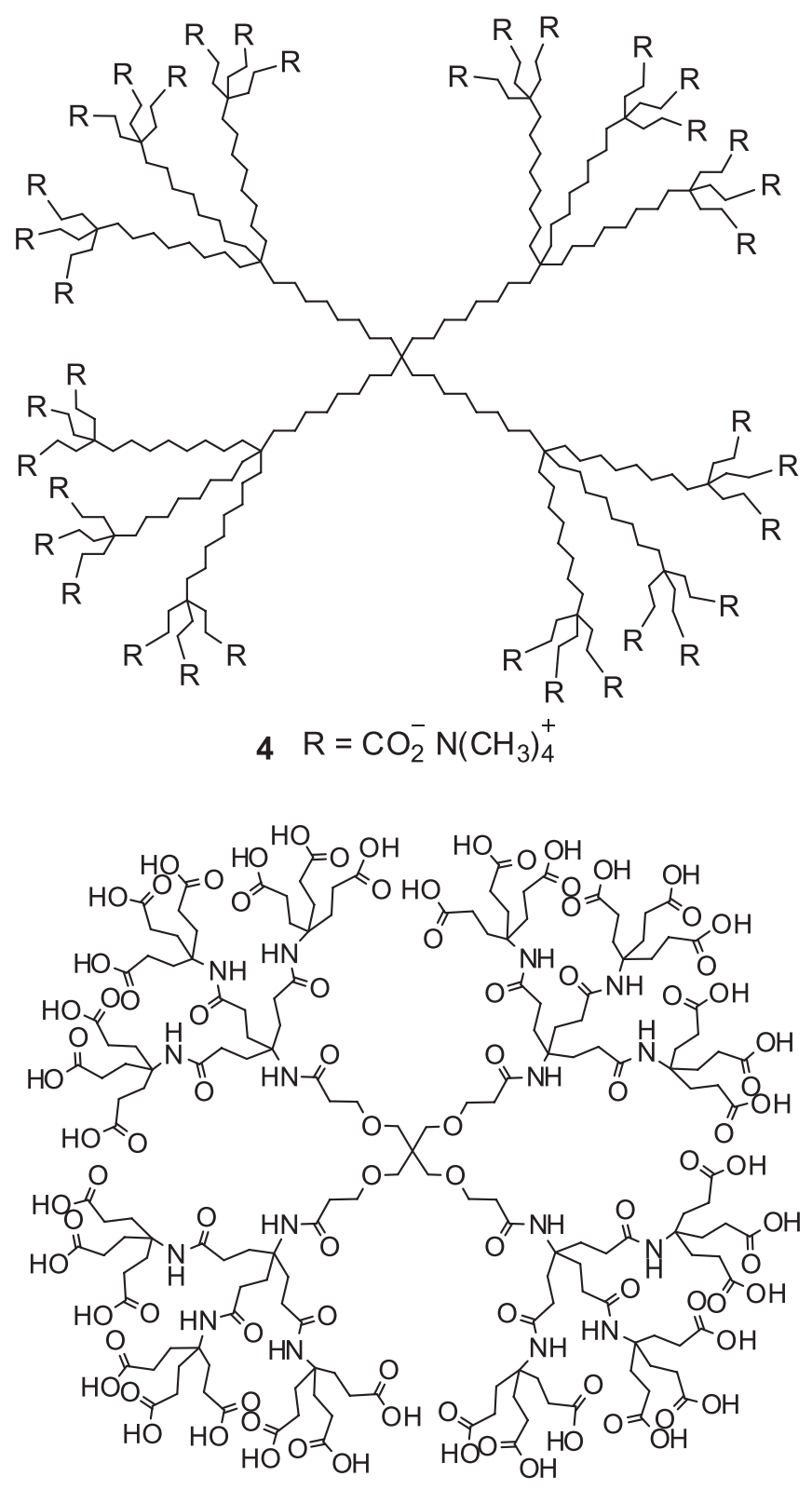

5

FIGURE 4 - Unimolecular micelles with an all-saturated, hydrocarbon (4) and amide-based (5) interiors [Newkome, G. R.; Moorefield, C. N.; Baker, G. R.; Johnson, A. L.; Behera, R. K. Angew. Chem., Int. Ed. Engl., v.30, p.1176-1178, 1991 - Reproduced by permission of Wiley-VCH; Young, J. K.; Baker, G. R.; Newkome, G. R.; Morris, K. F.; Johnson, C. S., Jr. Macromolecules, v.27, p.3464-3471, 1994 - Reproduced by permission of The American Chemical Society].

parabens and in a separate experiment, the components of cough syrup, were separated, thereby demonstrating the sensitivity of the method. The incorporation of 2,6-diamidopyridine units onto the internal arms of the dendrimer (6, Figure 5) placed four, hydrogen-bonding urea-type 
receptor groups within the framework (Newkome et al., 1996).

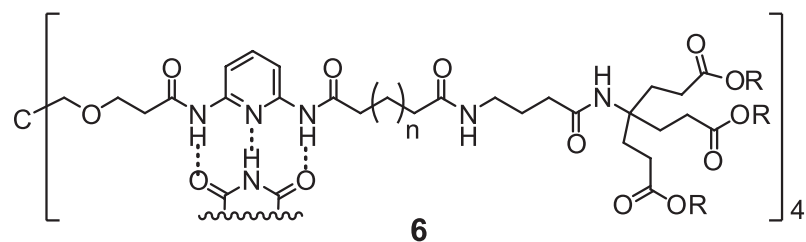

6
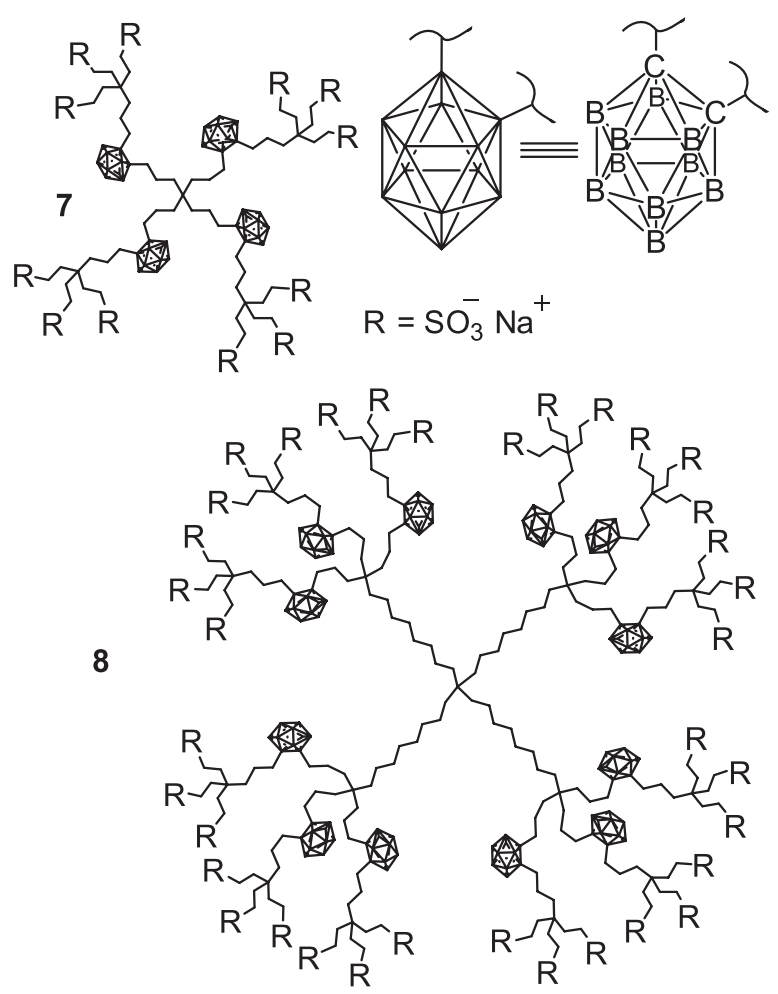

FIGURE 5 - Modification of the dendritic framework can easily facilitate drug delivery and cancer therapies [Newkome, G. R.; Moorefield, C. N.; Keith, J. M.; Baker, G. R.; Escamilla, G. H. Angew. Chem. Int. Ed. Engl., v.33, p.666-668, 1994 - Redrawn with permission of Wiley-VCH].

The $H$-bonding encapsulation of the cancer fighting drug AZT (3'-azido-3'-deoxythimidine) was demonstrated with this dendrimer and later, their use as sensors for the detection of the presence of organic solvents was exploited (Miller et al., 1998).

We have employed the polyalkyne dendritic precursors of the micellanoic acid series as scaffolding for the site specific incorporation of decaborane $\left(\mathrm{B}_{10} \mathrm{H}_{14}\right)$ within a dendritic framework due to interest in Boron Neutron Cancer Therapy (BNCT) (Newkome et al., 1994). Thus, the reaction of decaborane with the $1^{\text {st }}$ and $2^{\text {nd }}$ generation alkyne dendrimers afforded the poly(1,2-dicarba-closododecaboranes) 7 and $\mathbf{8}$, respectively. The alcohol termini of the $o$-carborane superclusters were rendered water soluble by transformation to the corresponding polysulfate analogs.

\section{MOLECULAR FRACTAL DESIGN AND UTI- LITY}

The past several years have witnessed increased interest in the general topic of metallo-fractal materials, particularly in relation to their future nanotechnological applications. Thus, projected research directions will build on the melding of classical synthetic strategies with materials science construction and characterization protocols to fine-tune bulk and localized supramolecular properties to specific tasks, and to assemble macromolecular infrastructures capable of functioning alone or in concert within materials at composite interfaces.

The art of macromolecular construction has evolved to include utilitarian composite materials; whereby, interdependent components are precisely matched for the desired physicochemical properties. Targeted materials and properties, derived from minimum-assembly protocols, are therefore of interest from various perspectives that include the ease of architecturally complex construction and commercial viability. The preparation of new monomers with bonding metal center(s) leading to new predesigned macro- and nano-scale constructs includes: branching multiplicity and choice of branching moieties (e.g. monoor polyatomic), length and flexibility of connector units, coupled with localized and aggregate supramolecular properties. Research efforts in our laboratories suggest that fundamental supramacromolecular properties can be affected by subtle changes in these design parameters.

These fractal constructs have led to the development of materials with demonstrated potential as: molecular batteries, switches, and optical display devices, to name but a few (Figure 6) (Schubert et al., 2006; Winter et al., 2011a,b; Friebe et al., 2012). Hence, our research directions necessarily encompass studies on terpyridine-metalterpyridine " $<$ tpy-M-tpy $>$ " connectivity employing preconstructed synthons to facilitate the one-step construction (as opposed to the multi-step construction of dendrimers) of nano- and macroscopic, precisely positioned, polymetal arrays giving rise to new precise multicomponent macromolecular systems.

Initial work (Newkome et al., 1999) resulted in the single-step, high yield, self-assembly of a hexaruthenium macrocycle (9, Figure 7) possessing the ubiquitous benzenoid architecture derived from the $120^{\circ}$ juxtaposed ditopic ligand, 3,5-bis(terpyridinyl)toluene. The resultant metallomacrocycle supports a $12^{+}$charge and was isolated as the 


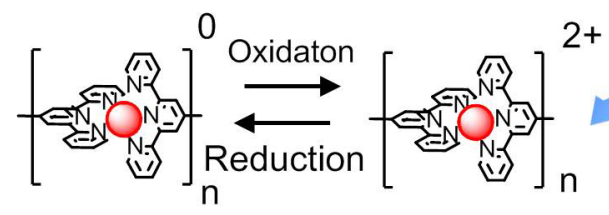

(a)

(b)

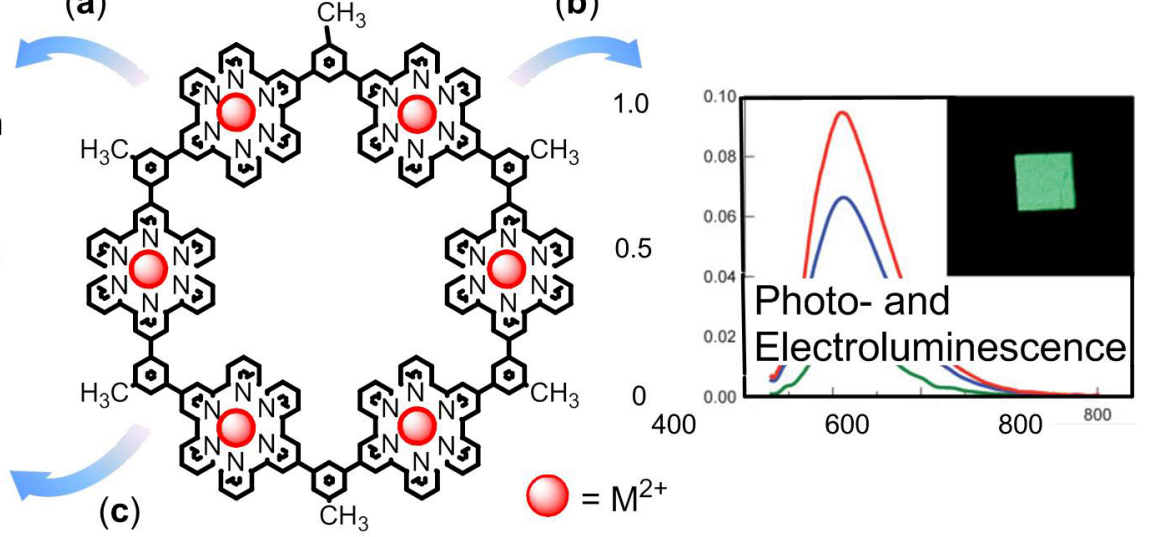

FIGURE 6 - Potential areas of utility for metallofractal materials include (a) energy storage and release, (b) optical devices, and (c) molecular switches.

$\mathrm{Cl}^{-}$; ion exchange to the $\mathrm{PF}_{6}{ }^{-}$salt facilitated characterization and solubility in common organic solvents. Structural confirmation of this original hexameric, multi-metal array was supported by TEM imaging.

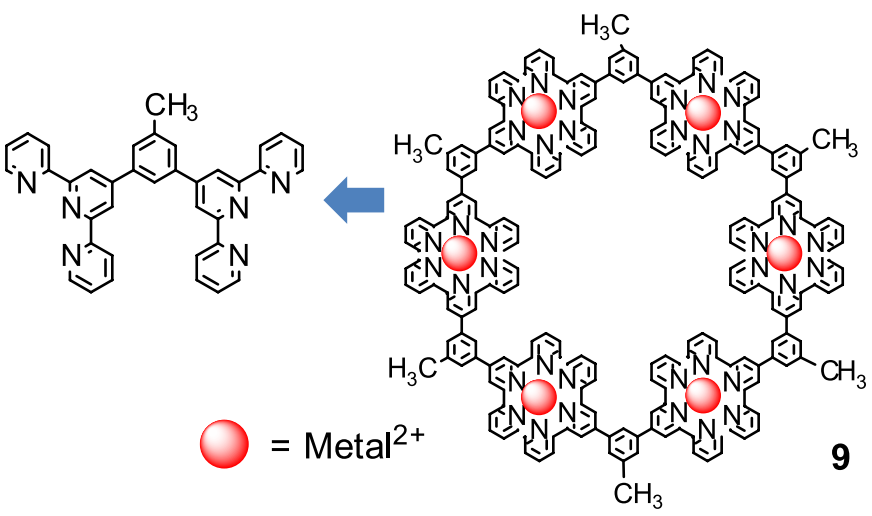

FIGURE 7 - Self-assembly of a bisterpyridine ligand possessing $120^{\circ}$ directionality affords a hexameric, metallomacrocycle.

From the observation that these multimetal arrays readily aggregate into larger assemblies that may present opportunities to prepare new materials with unique properties, we have investigated the ion-promoted, stoichiometric self-assembly of nanoscale composite fibers. Combining a structurally rigid hexameric macrocycle $\left[\left(\mathbf{1 0}^{12+}\right)\left(\mathrm{PF}_{6}{ }^{-}\right)_{12}\right]$ and a flexible, dodecacarboxylate-terminated, first generation, $1 \rightarrow 3$ branched dendrimer $\left[\left(\mathbf{1 1}^{12-}\right)\right.$ $\left(\mathrm{Na}^{+}\right)_{12}$; (see Figure 1 and the accompanying text for an introduction to these materials] gave rigid fibers (Wang et al., 2008) $\left[\left(\mathbf{1 0}^{12+}\right)\left(\mathbf{1 1}^{12-}\right)\right]_{\mathrm{n}}$ as revealed by TEM images (12, Figure 8).

The hydrodynamic diameter for the dendrimer of 23.6 Å determined under basic $\mathrm{pH}$ conditions using 2D dif-

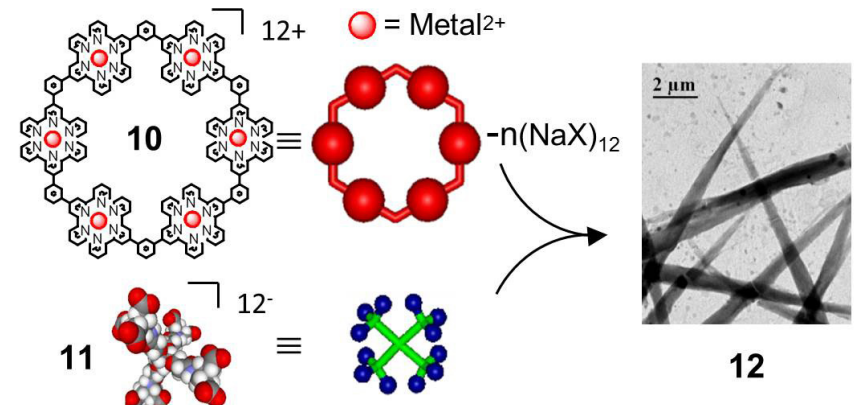

FIGURE 8 - Self-assembly of a dendrimer hexamer composite [Wang, P.; Moorefield, C. N.; Jeong, K.-U.; Hwang, S.-H.; Li, S.; Cheng S. Z. D.; Newkome, G. R. Adv. Mater., v.20, p.1381-1385, 2008. - Reproduced by permission of Wiley-VCH].

fusion ordered spectroscopy (DOSY) NMR experiments (Young et al., 1994) is larger than the internal open area diameter $(17.5 \AA)$ of the hexamer. This suggests that an ordered, molecular packing of the two components could be based on the dendrimer fitting above (and below) the cavity of the hexamer, and only partially into it.

Insight into the composites molecular ordering was obtained with selected area electron diffraction (SAED) of the fibers (i.e., 12). Two strong electron diffractions perpendicular to the fibers long axis were observed with a $d$-spacing of $3.85 \mathrm{~nm}$; diffused higher diffractions were also observed. As well, a $d$-spacing of $1.92 \mathrm{~nm}$ was obtained from a pair of intense diffraction patterns parallel to the fiber's long axis. This suggests that the in-plane direction of $\left(\mathbf{1 0}^{12+}\right)$ is perpendicular to the long axis and that self-assembly results in alternating stacking of the two components. With the impetus to explore the properties of triangular metallocycles, (Schultz et al., 2011) three new ligands (13 - 15; Figure 9) possessing $60^{\circ}$ direction- 


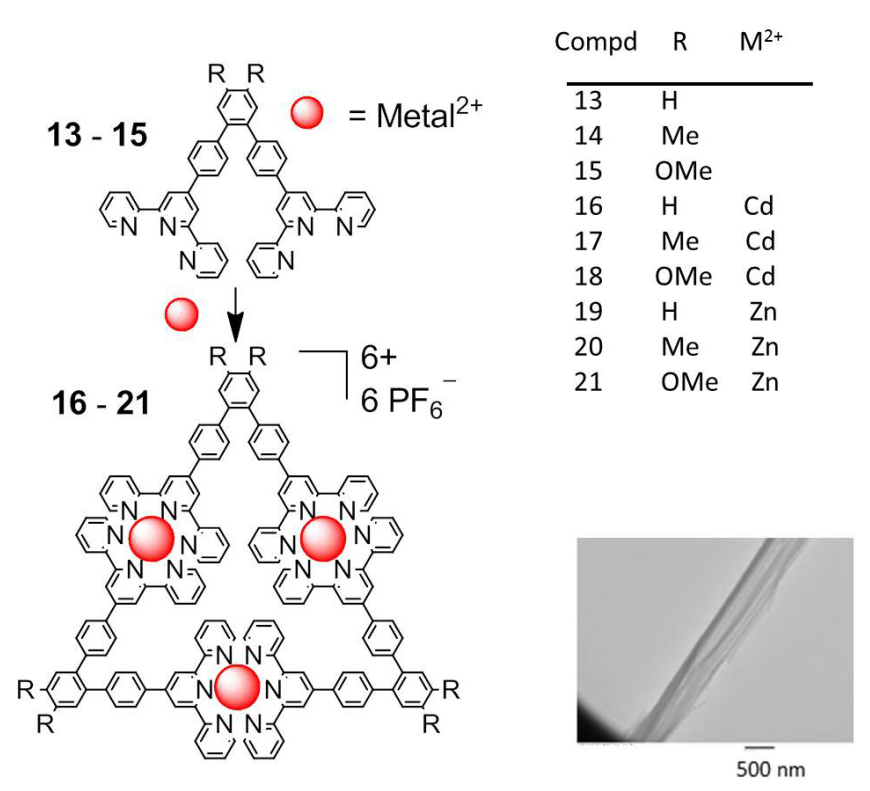

FIGURE 9 - Synthesis of a series of triangular metallocycles and a TEM image of fibers readily formed when the molecular triangles are paired with benzenehexacarboxylate [Schultz, A.; Cao, Y.; Huang, M.; Cheng, S. Z. D.; Li, X.; Moorefield, C. N.; Wesdemiotis, C.; Newkome, G. R. Dalton Trans., v.41, p.1157311575, 2012. - Reproduced by permission of The Royal Society of Chemistry].

ality were prepared by Suzuki coupling with known aryl 1,2-dihalides and 4- terpyridinylphenylboronic acid. Treatment of the $60^{\circ}$-based bisterpyridines with either $\mathrm{Cd}^{2+}$ or $\mathrm{Zn}^{2+}$ generated a series of triangular materials (16-21) that were observed to form fibers following counterion exchange with benzenehexacarboxylate. The linear, hairlike fibers were obtained using a mixed solvent system prepared from dilute solutions $(\sim 1 \mathrm{mM})$ of metallocycle in $\mathrm{MeCN}$ and sodium hexabenzoate in water. TEM images revealed large bundled structures with cross-sections of ca. $300 \mathrm{~nm}$ comprised of narrower fiberous strands of $c a$. $2.0 \mathrm{~nm}$.

Rigorous characterization of these molecular triangles included electrospray ionization mass spectrometry (ESI-MS) in concert with traveling-wave ion mobility mass spectrometry (TWIM-MS), along with gradient tandem mass spectrometry $\left(\mathrm{gMS}^{2}\right)$ that corroborated the stability of the triangles observed in the TWIM spectra.

Powder X-ray diffraction (XRD) data were obtained from microcrystalline regions within the fibers. Combined with SAXD data orthorhombic unit cell dimensions of $39.82,8.38$, and $49.14 \AA$ for a, b, and c, respectively, were determined and a packing model for the triangles in the fiber was suggested using computer generated molecular modeling (Figure 10).

In general, self-assembly techniques lead to the most thermodynamically stable product(s), while kinetic control is required to access the less stable products. For example, kinetic control can be affected by utilizing nonreversible connectivity to achieve the desired target or by the removal of the potential for the formation of the enthalpically favored product.

Whereas, we have demonstrated the high yield synthesis of trimeric metallocycles by the self-assembly of $60^{\circ}$-based bisterpyridines, the dimerization of these
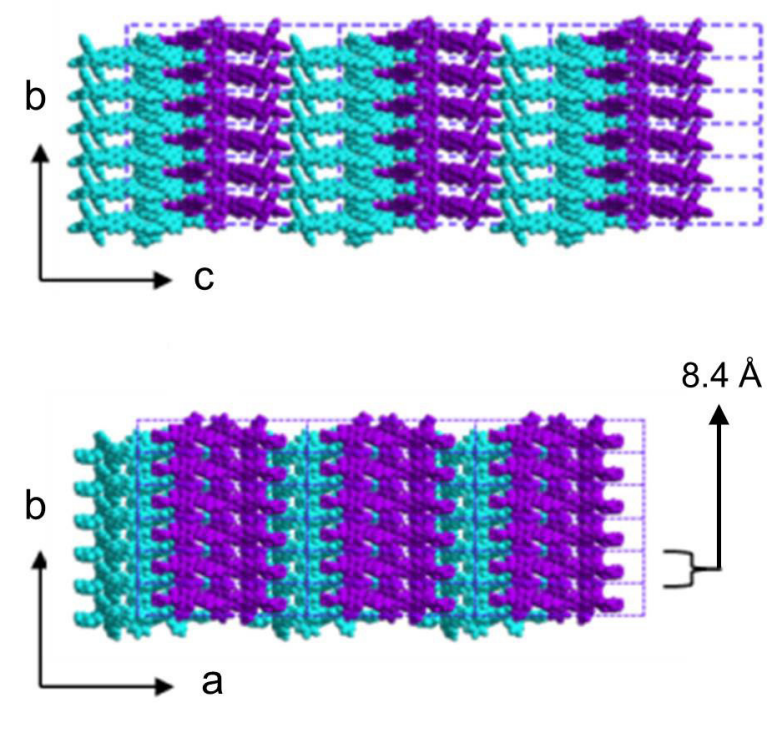

FIGURE 10 - Proposed fiber packing model for triangle 20 [Schultz, A.; Cao, Y.; Huang, M.; Cheng, S. Z. D.; Li, X.; Moorefield, C. N.; Wesdemiotis, C.; Newkome, G. R. Dalton Trans., v.41, p.11573-11575, 2012. - Reproduced by permission of The Royal Society of Chemistry]. 
bisligands using a strongly binding metal that renders the complex non-reversible leading to the formation of folded molecular squares (Schultz et al., 2012b) upon self-assembly with itself.

Starting with ligand 15 (Figure 9) dimerization was achieved by a stoichiometrically controlled reaction with $\mathrm{RuCl}_{2}(\mathrm{DMSO})_{4}$ in $\mathrm{CHCl}_{3}: \mathrm{MeOH}(1: 1 \mathrm{v} / \mathrm{v})$ to generate the new bisligand 22 (Figure 11).

Self-assembly with $\mathrm{Ru}^{2+}, \mathrm{Fe}^{2+}, \mathrm{Zn}^{2+}$, and $\mathrm{Cd}^{2+}$ gave the corresponding tetramers $\mathbf{2 3}-\mathbf{2 6}$, respectively. For the $\mathrm{Cd}^{2+}$ and $\mathrm{Zn}^{2+}$ products, purification was achieved by simple counterion exchange with $\mathrm{NH}_{4} \mathrm{PF}_{6}$; whereas, the $\mathrm{Fe}^{2+}$ and $\mathrm{Ru}^{2+}$ tetramers required column chromatography. Notably, a one-pot reaction of ligand 15 with $\mathrm{FeCl}_{2} \cdot 4 \mathrm{H}_{2} \mathrm{O}$ afforded (8\%) tetramer $\mathbf{2 4}$, along with the expected trimer in $29 \%$ yield after chromatography. In addition to NMR, ESI-MS, TWIM-MS, and photophysical characterization, gradient tandem MS $\left(\mathrm{gMS}^{2}\right)$ revealed an order of stability for stability order of $<$ tpy-M ${ }^{2+}$-tpy $>$ as $\mathrm{Cd}^{2+}<\mathrm{Zn}^{2+}<\mathrm{Fe}^{2+}$
$<\mathrm{Ru}^{2+}$, as expected. Owing to the folded shape of the tetramers (Figure 12), the descriptive term "Dondorff" rings was coined after the first person to describe the giant manta ray.

In an earlier report, we delineated the concept of larger, dimerized, bisterpyridine ligands to afford a series of heteronuclear hexameric, octameric, and decameric metallo-cycles (Chan et al., 2011a) via stepwise selfassembly procedures. In this case, the new bisligand (27, Figure 13) was constructed using a $120^{\circ}$-based building block architecture. As in the case of the $60^{\circ}$-juxtaposed starting ligand, the formation of smaller metallocycles is circumvented by using a longer building block, as the precursor. Traveling wave ion mobility mass spectrometry (TWIM-MS) and molecular modeling provided insight into their unique sizes and conformational flexibility.

Dimer 27 was isolated (29\%) following column chromatography from a single-pot reaction of the cor-
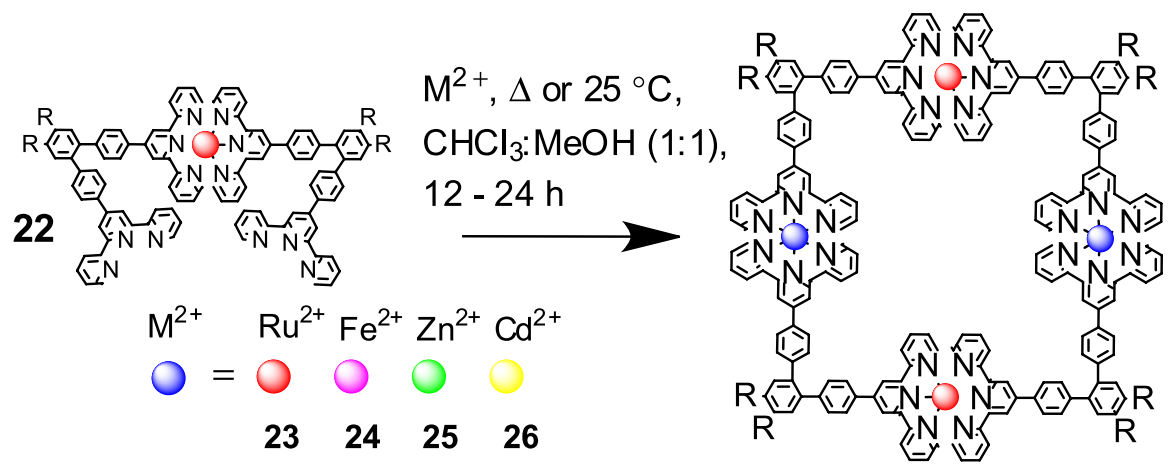

FIGURE 11 - Synthesis of a series of square-shaped metallocycles using a modified bisterpyridine to avoid trimer formation [Schultz, A.; Li, X.; McCusker, J. K.; Moorefield, C. N.; Castellano, F. N.; Wesdemiotis, C.; Newkome, G. R. Chem. Eur. J., v.18, p.11569-11572, 2012. - Reproduced by permission of Wiley-VCH].

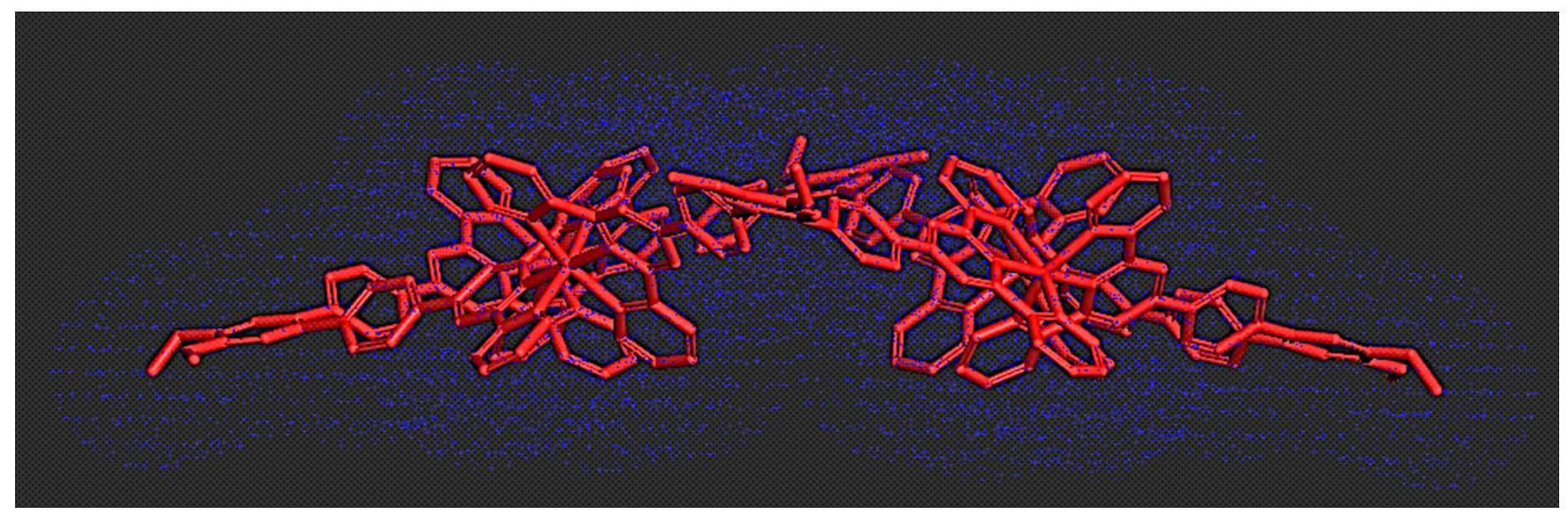

FIGURE 12 - Side view of a computer generated model of a tetrameric Dondorff ring showing the folded motif [Schultz, A.; Li, X.; McCusker, J. K.; Moorefield, C. N.; Castellano, F. N.; Wesdemiotis, C.; Newkome, G. R. Chem. Eur. J., v.18, p.11569-11572, 2012. - Reproduced by permission of Wiley-VCH]. 

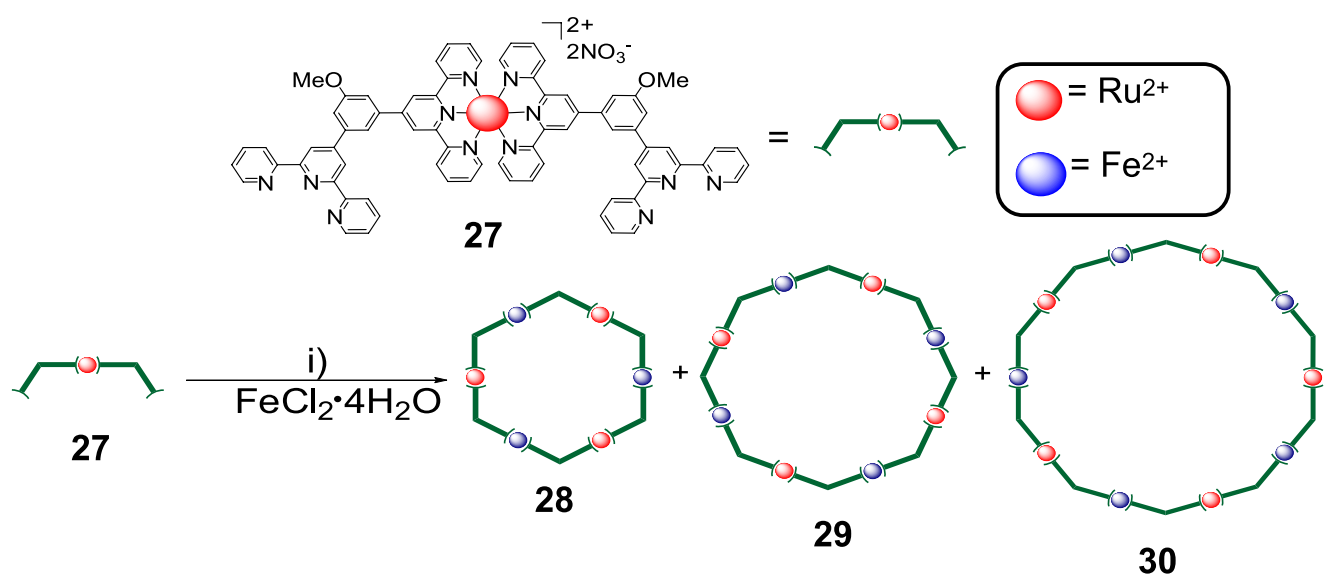

FIGURE 13 - Synthesis of a series of heteronuclear metallocycles using a modified bisterpyridine to minimize the formation smaller materials [Chan, Y.-T.; Li, X.; Moorefield, C. N.; Wesdemiotis, C.; Newkome, G. R. Chem. Eur. J., v.17, p.7750-7754, 2011 - Reproduced by permission of Wiley-VCH].

responding $120^{\circ}$-based bis(terpyridine) ligand with 0.5 equivalent of $\mathrm{RuCl}_{2}(\mathrm{DMSO})_{4}$. Treatment of $\mathbf{2 7}$ with 1.05 equivalents of $\mathrm{FeCl}_{2} \cdot 4 \mathrm{H}_{2} \mathrm{O}$ in $\mathrm{MeOH}$ afforded hexamer 28, octamer 29, and decamer $\mathbf{3 0}$ in 36, 9, and 2\% yields, respectively, after column chromatography.

The specific geometries of the different macrocycles and their cross-sectional areas were investigated using molecular modeling and annealing simulations. The obtained collision cross-section $v s$. relative energy plots exhibited three distinct areas, corresponding to three ma- jor regions of conformations, circular, twisted stretched, twisted folded. Whereas, when rigid ligands are used to construct the macrocycles, the overall flexibility of the larger polycomplexes increases with size, leading to a wider range of possible geometries. Flexibility is thus greatest for decamer 30 (Figure 14), where several different conformers are possible.

Expanding on the concept of enlarging bisligand building blocks for the construction of otherwise not easily accessible macrocycles, a trimeric ligand $\mathbf{3 1}$ has been

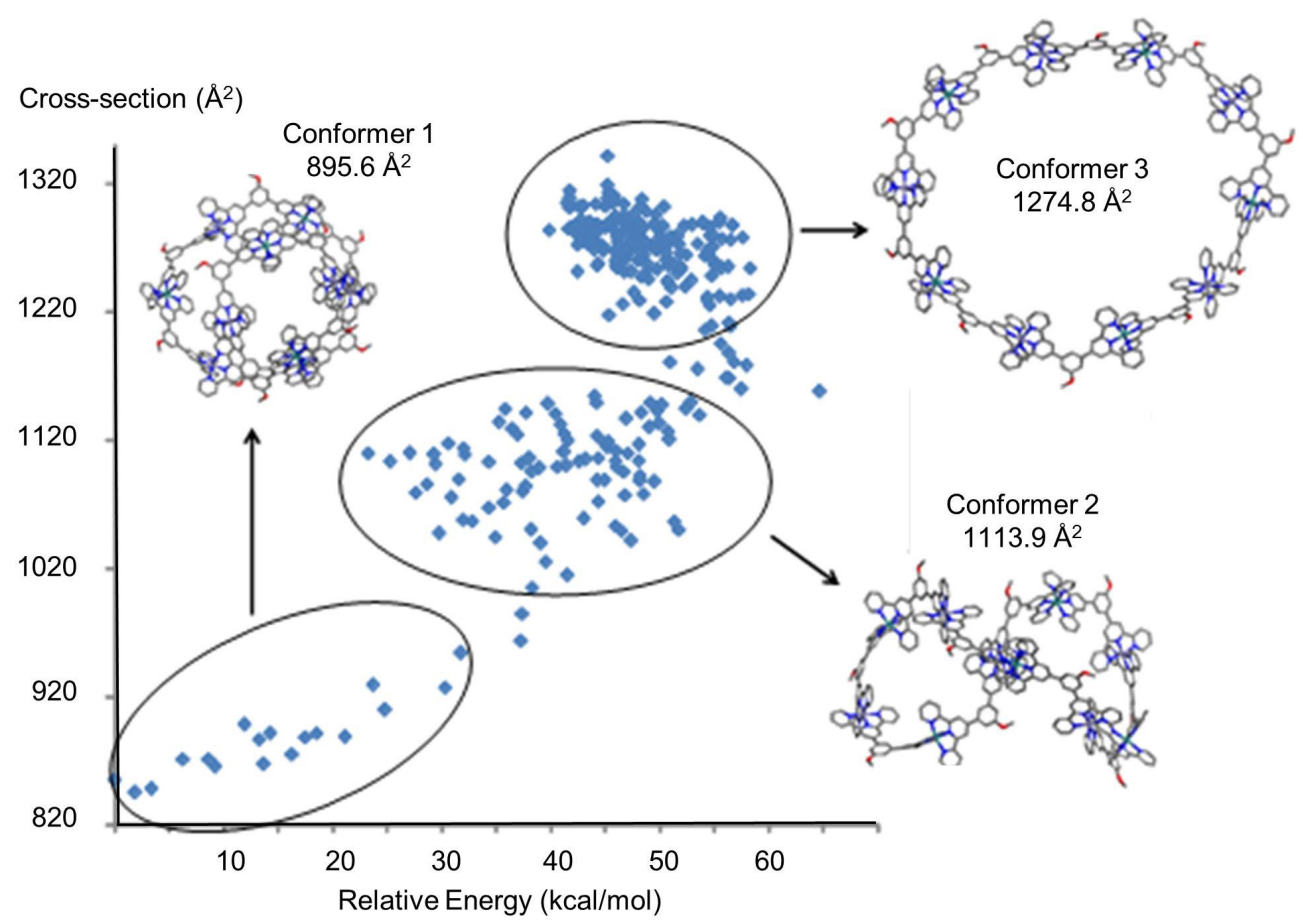

FIGURE 14 - Annealing experiments facilitated a plot of collision cross-sections $v s$. relative energies for complex $\mathbf{3 0}$ revealing three general groupings of conformers [Chan, Y.-T.; Li, X.; Moorefield, C. N.; Wesdemiotis, C.; Newkome, G. R. Chem. Eur. J., v.17, p.7750-7754, 2011 - Reproduced by permission of Wiley-VCH]. 
conceived and isolated. (Chan et al., 2011b) Following a two-step reaction sequence, whereby bisterpyridine 32 was treated with 2 equivalents of $\mathrm{RuCl}_{3}$ to give the paramagnetic bis $\mathrm{Ru}^{3+}$ adduct, which upon addition of 2 equivalents of $\mathbf{3 1}$ under reductive conditions afforded the desired trimer (Figure 15). Incorporating bisterpyridine 32 into the same two-step sequence gave (80\%) the desired hexaRu ${ }^{2+}$ metallocycle 33 . Reaction of trimer 32 with $\mathrm{FeCl}_{2}$ in refluxing $\mathrm{CH}_{3} \mathrm{OH}$ for $18 \mathrm{~h}$ generated the heteronuclear hexamer 34 and nonamer 35 in 49 and 14\% yields, respectively. Along with characterization by ESITWIM-MS, ${ }^{1} \mathrm{H}$ and ${ }^{13} \mathrm{C}$ NMR, absorption spectroscopy and molecular modeling, 2D DOSY (diffusion ordered spectroscopy) supported the similar ring sizes of the two hexamers, as well as the larger nonamer; diffusion coefficients of $4.57 \times 10^{-10}, 4.51 \times 10^{-10}$, and $3.31 \times 10^{-10} \mathrm{~m}^{2} / \mathrm{s}$ were recorded for the homo- and hetero-nuclear hexamers and heteronuclear nonamer, respectively (Figure 16).

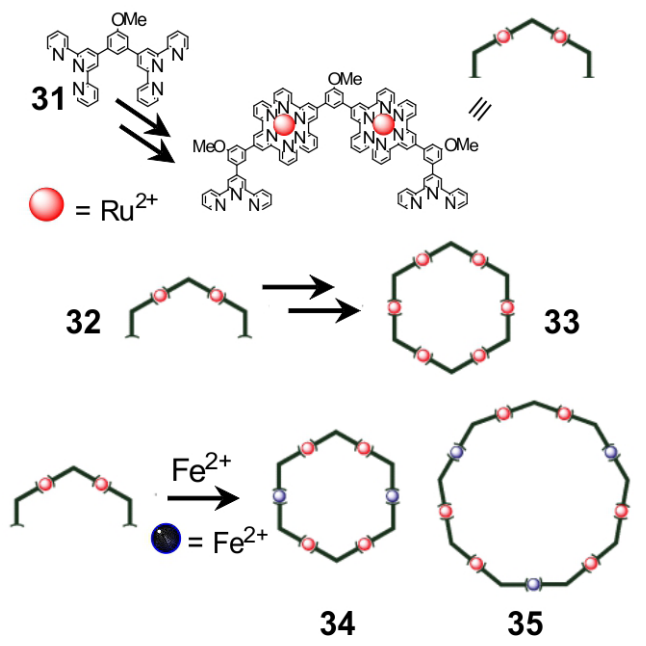

FIGURE 15 - Construction of a trimeric building block facilitated the synthesis of a large, nine-membered ring and homo- and hetero-nuclear hexamers in good yields [Chan, Y.-T.; Li, X.; Yu, J.; Carri, G. A.; Moorefield, C. N.; Newkome, G. R. J. Am. Chem. Soc., v.133, p.11967-11976, 2011. - Reproduced by permission of The American Chemical Society].

Efforts aimed at the construction of pentameric metallomacrocycles have utilized carbazole derivatives to introduce the requisite angle (Hwang et al., 2005). Thus, employing a 3,6-disubstituted carbazole unit between two ligands gave a $105^{\circ}$ angle between two the terpyridine ligands (i.e., 36, Figure 17). Treatment of the carbazolebased bisterpyridine with $\mathrm{Ru}^{2+}, \mathrm{Fe}^{2+}$ or $\mathrm{Zn}^{2+}$ gave the corresponding metall-ocycles $\mathbf{3 7} \mathbf{- 3 9}$.

Employed as sensitizer materials for solar cell devices, discharge experiments were conducted with
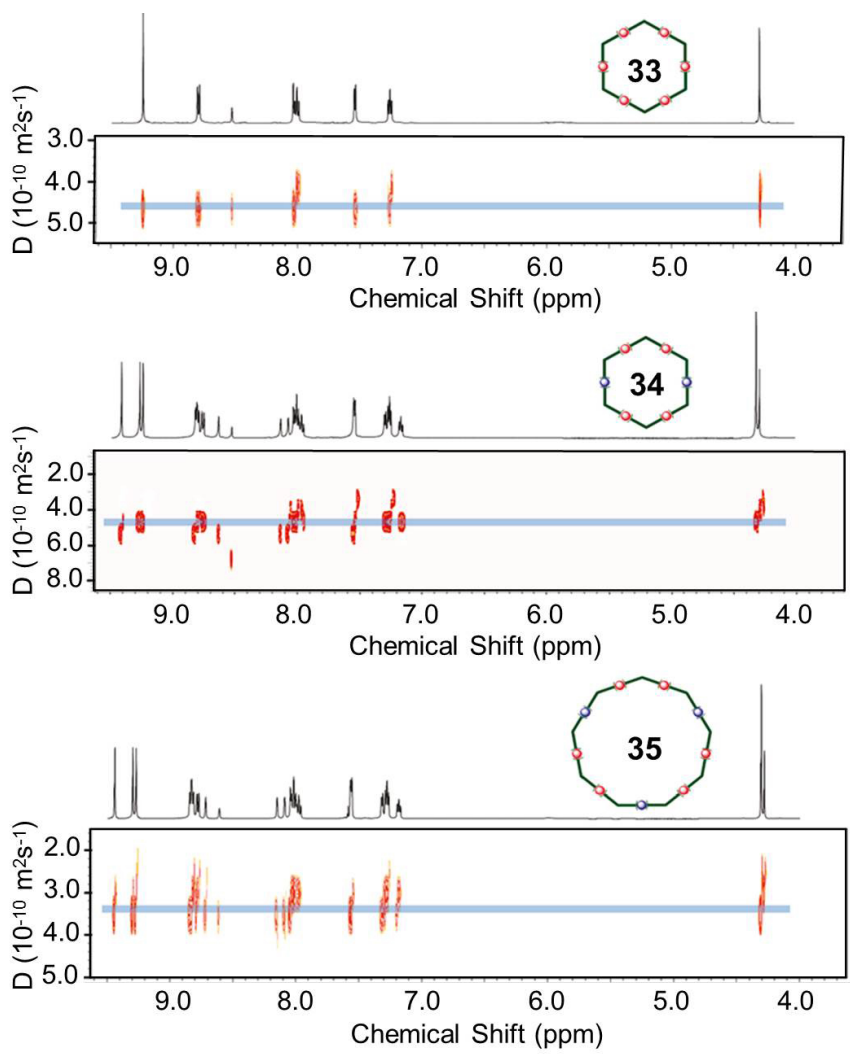

FIGURE 16 - 2D Diffusion Ordered Spectroscopy (DOSY) NMR confirmed ring size [Chan, Y.-T.; Li, X.; Yu, J.; Carri, G. A.; Moorefield, C. N.; Newkome, G. R. J. Am. Chem. Soc., v.133, p.11967-11976, 2011. - Reproduced by permission of The American Chemical Society].

these materials. A similar fill factor $(f f)$ was observed for the three electrodes studied, while both the short circuit photocurrent $\left(j_{s c}\right)$ and the open circuit photopotential $\left(V_{o c}\right)$ exhibited the best results for the $\mathrm{Ru}^{2+}$ metallopentacycle. As well, photoconversion efficiency $(\eta)$ using light covering the visible region of the spectrum again showed that the $\mathrm{Ru}^{2+}$ pentamer 37 possessed the highest value.

After modifying a $120^{\circ}$-based bisterpyridine ligand with an acetyl protected sugar moiety with the expectation of crafting a peripherally functionalized, hexameric metallomacrocycle, we isolated (4\%) a unique pentameric construct, (Chan et al., 2010) along with the anticipated hexameric species (12\%). Thus, the $\mathrm{Fe}^{2+}$-based pentamer 40 - characterized unequivocally by 2D COSY NMR and ESI-MS - represents the first example of a smaller ring being obtained from the self-assembly of rigid, $120^{\circ}$-juxtaposed terpyridine ligands. A noticeable difference in the ${ }^{1} \mathrm{H}$ NMR of the pentamer in contrast to the hexamer was the upfield shift of the absorption attributed to the $4 \mathrm{Ar} H$, that is oriented towards the interior of the ring; a slightly enhanced crowding effect for the five-membered specie was postulated. All other NMR absorptions for both rings was similar. 

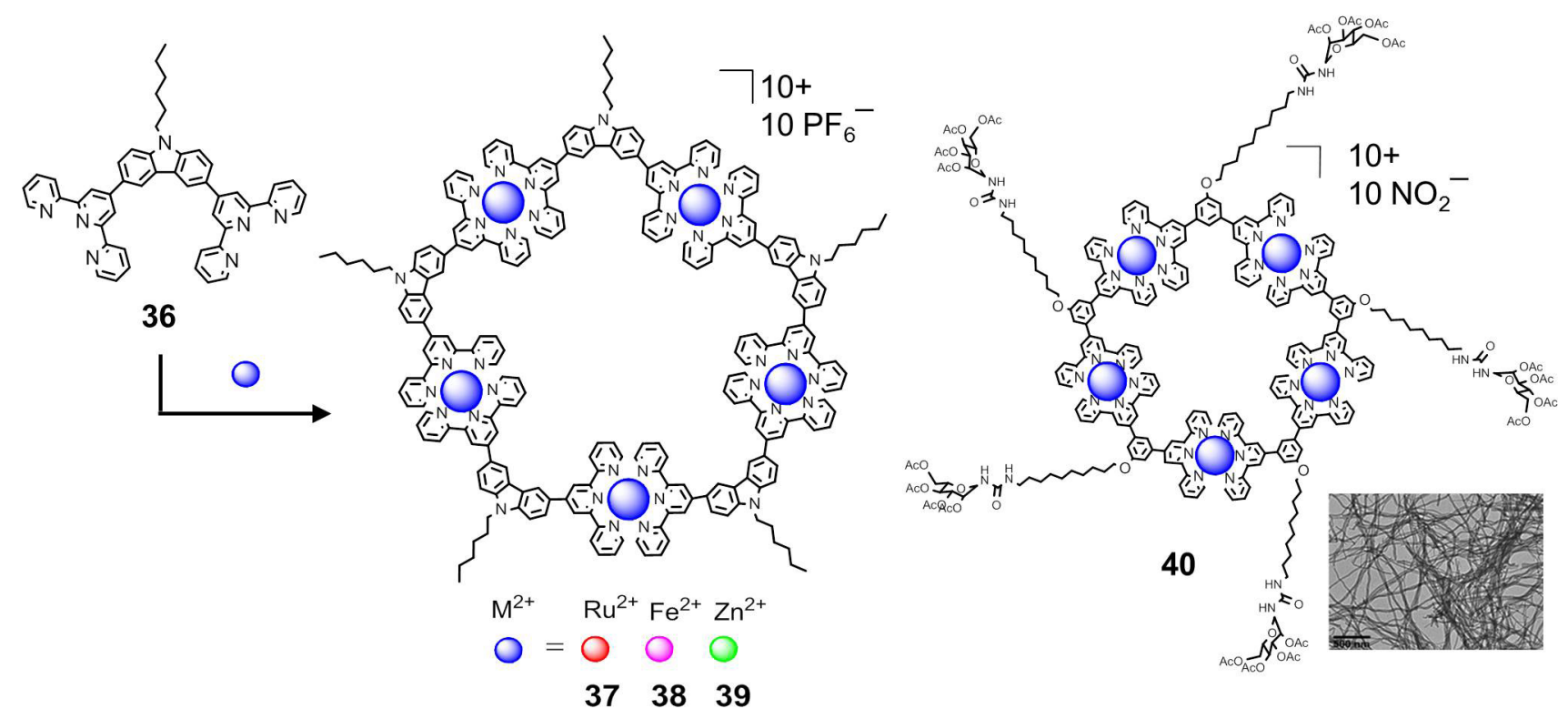

FIGURE 17 - Carbazole-based rings showed promise as sensitizers and sugar-coated rings self-assemble to form fibers [Hwang, S.-H.; Wang, P.; Moorefield, C. N.; Godinez, L. A.; Manriquez, J.; Bustos, E.; Newkome, G. R. Chem. Commun., p.4672-4674, 2005. - Reproduced by permission of The Royal Chemistry Society; Chan, Y.-T.; Moorefield, C. N.; Soler, M.; Newkome, G. R. Chem. Eur. J., v.16, p.1768-1771, 2010. - Reproduced by permission of Wiley-VCH].

Both the five- and six-membered rings formed fibers when hexane was allowed to diffuse into a solution of the macrocycle in a $\mathrm{CHCl}_{3}: \mathrm{MeOH}: \mathrm{MeCN}$ mixture $(8: 3: 1 \mathrm{v} / \mathrm{v})$. In each case, fiber lengths and diameters of 10-80 $\mathrm{nm}$ and 20-30 $\mathrm{nm}$ were observed, respectively. Molecular modeling of the rings showed interior void regions of $1.3 \mathrm{~nm}$ for the 5 -membered specie and $1.8 \mathrm{~nm}$ for the larger ring.

During 2009, our lab was searching for better thermodynamic control over the self-assembly of the metallomacrocycles; the use of $\mathrm{Cd}^{2+}$ to facilitate the terpyridine-terpyridine connectivity provided that kinetic $v s$ thermodynamic balance. Thus, treatment of tert-butylmodified bisterpyridine $\mathbf{4 1}$ with a stoichiometric amount of $\mathrm{Cd}\left(\mathrm{NO}_{3}\right)_{2} \cdot 4 \mathrm{H}_{2} \mathrm{O}$ in $\mathrm{CHCl}_{3}: \mathrm{MeOH}(3: 2 \mathrm{v} / \mathrm{v})$ quantitatively generated the desired hexacadmium (Chan et al., 2009) macrocycle 42 (Figure 18). Due to the lability of the Cdterpyridine coordination, the thermodynamically most stabile product was formed; no other species (e.g., 5-, 7-, or 9-membered rings) were detected. The absence of oligomeric products in the reaction to form the macrocycles was verified by the preparation of a linear bisterpyridine building block, oligomerization with $\mathrm{Cd}$, and ESI-TWIMMS analysis for comparison to patterns and drift times observed for hexamer $\mathbf{4 2}$.

Ions selected for ion mobility separation included $[6 \mathrm{~L}+6 \mathrm{Cd}]^{4+}$ and $[3 \mathrm{~L}+3 \mathrm{Cd}]^{2+}$, based on the small number of ligand-to-metal possible combinations. Ion mobility separation signals for the cyclic and linear fragments generated from the cyclic material occurred at shorter drift times (i.e., $10.30,6.45$, and $5.13 \mathrm{~ms}$ for the $[3 \mathrm{~L}+3 \mathrm{Cd}]^{2+}$ ion and linear and cyclic $[6 \mathrm{~L}+6 \mathrm{Cd}]^{4+}$ ions, respectively) then the signals for same $\mathrm{m} / \mathrm{z} 1187$ amu-based fragments observed in the case of the linear construct (i.e., 11.55 and $6.59 \mathrm{~ms}$ for linear $[3 \mathrm{~L}+3 \mathrm{Cd}]^{2+}$ and the $[6 \mathrm{~L}+6 \mathrm{Cd}]^{4+}$ ions respectively). Drift times are longer for the linear building block material and no signals were seen near the lower drift time of $5.13 \mathrm{~ms}$, which confirmed that the 5.13 peak corresponds to the cyclic $[6 \mathrm{~L}+6 \mathrm{Cd}]^{4+}$ species and the $6.45 \mathrm{~ms}$ peak corresponds to the linear $[6 \mathrm{~L}+6 \mathrm{Cd}]^{4+}$ species. Thus, the linear fragments generated from the cyclic material in the mass spectroscopy instrument arise solely from the cyclic specie.

In a dramatic example of the synthetic potential that complementary geometric and thermodynamic control can achieve, the first terpyridine-based, nanoscale, supramolecular spoked wheel (Wang et al., 2011) was constructed in our laboratory. A three-component, singlestep, coordination-driven, self-assembly with tris- and hexakis-terpyridine polyligands, along with $\mathrm{Zn}^{2+}$ or $\mathrm{Cd}^{2+}$ ions reacted in a stoichiometric ratio, generated the $D_{6 \mathrm{~h}}$ symmetric product that was isolated in $>94 \%$ yield. Characterization of the product included TWIM-MS, diverse NMR techniques, and TEM imaging.

Tristerpyridine $\mathbf{4 3}$ and hexakisterpyridine $\mathbf{4 4}$ (Figure 19) were each prepared using Suzuki-type, cross- 


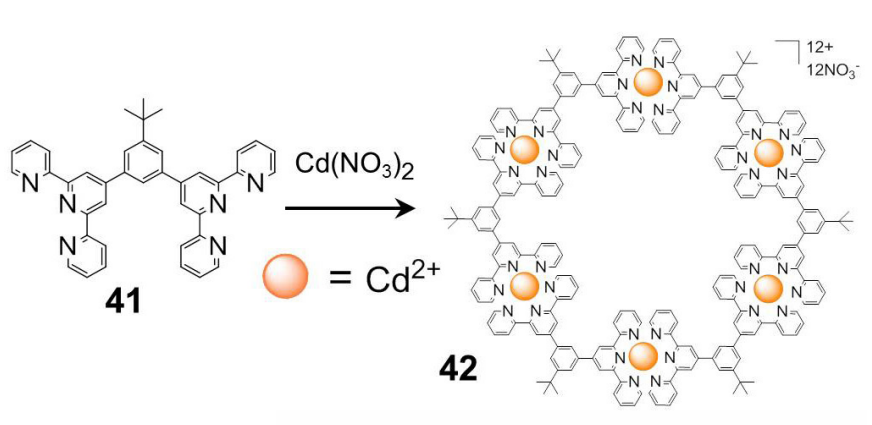

A

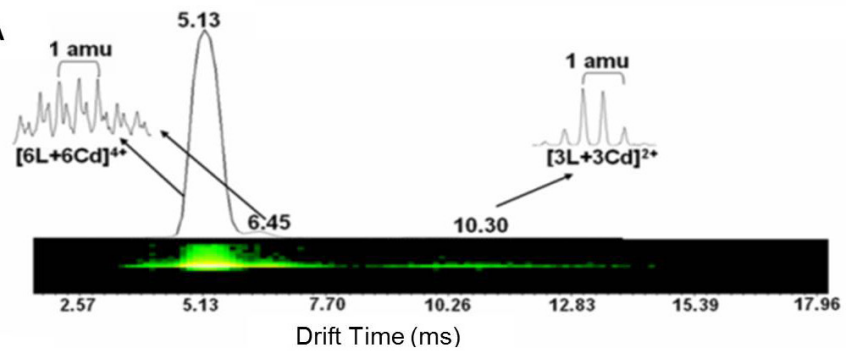

B

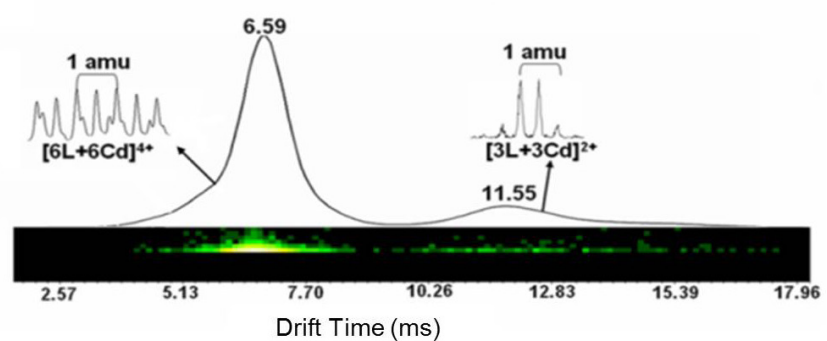

FIGURE 18 - Quantitative synthesis of a Cd-based hexamer 42. Its 2D ESI-TWIM-MS signals (7A) for $\mathrm{m} / \mathrm{z} 1187 \mathrm{amu}$ compared to the same ion fragments generated from a similar linear Cd construct (7B) [Chan, Y.-T.; Li, X.; Soler, M.; Wang, J.-L.; Wesdemiotis, C.; Newkome, G. R. J. Am. Chem. Soc., v.131, p.16395-16397, 2009 - Reproduced by permission of The American Chemical Society].

coupling reactions with 4-terpyridinyl-phenylboronic acid and the corresponding tri- or hexabromobenzene. Subsequent reaction of the two polyterpyridine ligands with $\mathrm{M}\left(\mathrm{NO}_{3}\right)_{2} \cdot 6 \mathrm{H}_{2} \mathrm{O}$ (where $\mathrm{M}=\mathrm{Cd}^{2+}$ or $\mathrm{Zn}^{2+}$ ) in a $\mathrm{CHCl}_{3} / \mathrm{MeOH}$ solution at $25^{\circ} \mathrm{C}$ for $30 \mathrm{~min}$ in a $1: 6: 12$ ratio, respectively, afforded the dodecaM ${ }^{2+}$ complex 45. The polynitrate form was converted to the $24 \mathrm{PF}_{6}{ }^{-}$salt to facilitate characterization.

The TEM supported the size and geometry of individual macromolecules revealing hexagonal-shaped, shadow-like images possessing average diameters of $6.5 \pm$ $1.0 \mathrm{~nm}$; this diameter corresponds well with the molecular modeling calculations showing a $5.6 \mathrm{~nm}$ diameter for the optimized structure.

The ability to create new materials with terpyridinebased self-assembly is limited only by the building blocks that are available and the imagination of the artist. In a
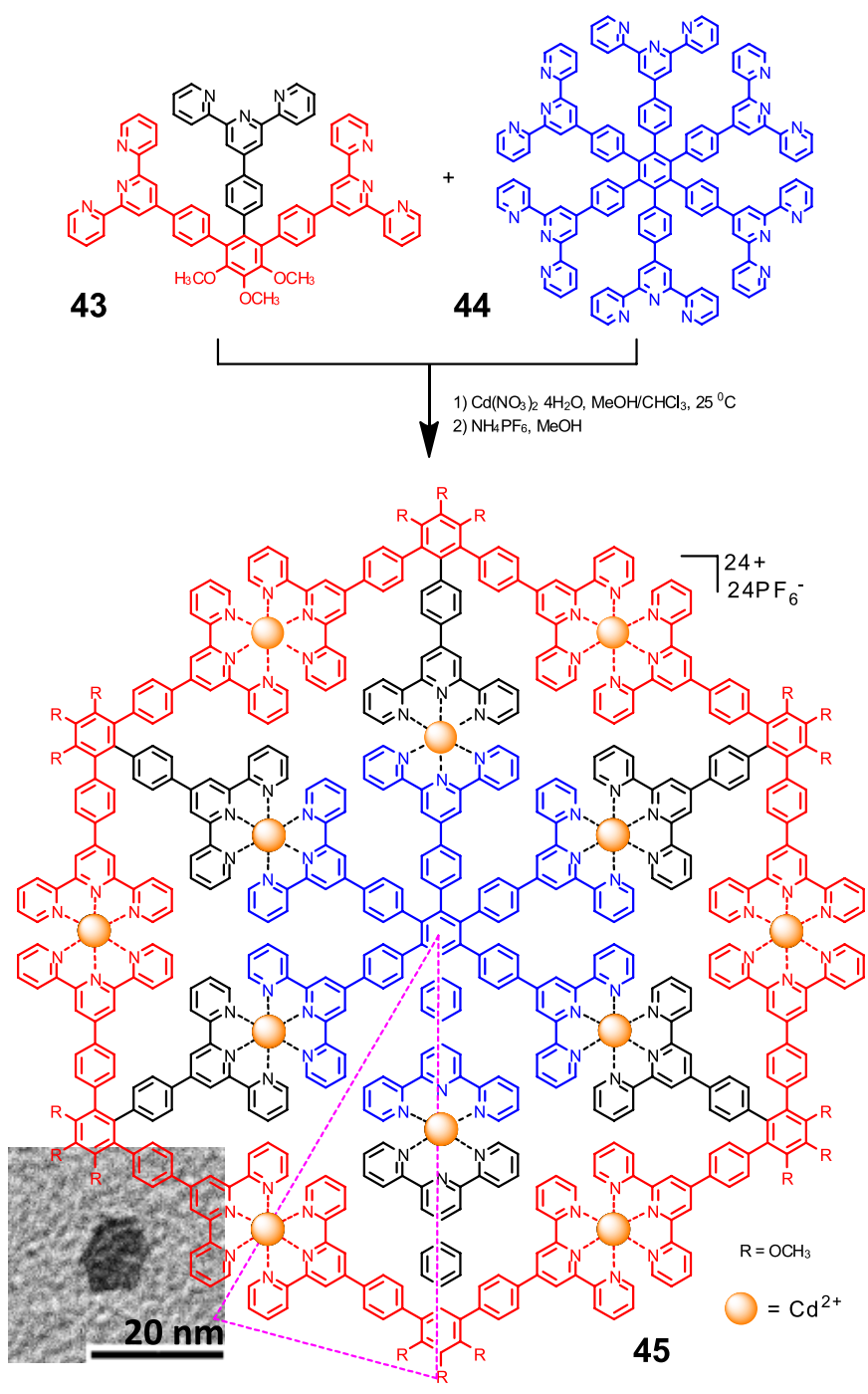

FIGURE 19 - Self-assembly of a $D_{6 \mathrm{~h}}$ symmetric, spoked wheel and its TEM image. The dotted line triangle represents the smallest repeating subunit of 45 [Wang, J.-L.; Li, X.; Lu, X.; Hsieh, I.-F.; Cao, Y.; Moorefield, C. N.; Wesdemiotis, C.; Cheng, S. Z. D.; Newkome, G. R. J. Am. Chem. Soc., v.133, p.1145011453, 2011. - Reproduced by permission of The American Chemical Society]

logical extension of the polyterpyridines used in the construction of the spoked wheel, other polybromides were sought that would allow access to unique starting materials. Ready availability of two additional tetrabromoaryl synthons facilitated the creation, via high yield Suzuki coupling reaction, of two isomeric tetrakisterpyridines (i.e., 46 and 47, Figure 20).

With these new terpyridines added to our molecular quiver, two polycyclic, macromolecular, constitutional isomers (Schultz et al., 2012a) were constructed (Figure $21)$. As in the case of synthesizing large ring structures, use of the dimeric terpyridine $\mathbf{4 8}$ restricted the degrees- 


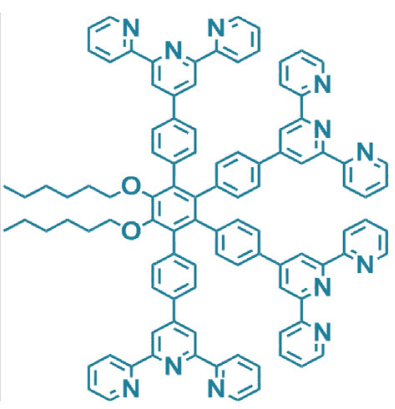

46

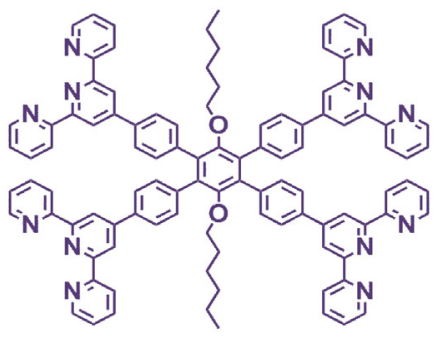

47
FIGURE 20 - Two new tetrakisterpyridine building blocks that facilitated the synthesis of constitutional isomers.

of-freedom of reaction and subsequently facilitated optimum conditions for isolation of either molecular bowtie 49 when reacted with tetrakisterpyridine $\mathbf{4 7}$ or the isomeric molecular butterfly motif $\mathbf{5 0}$ when treated with tetrakisterpyridine 46. Structural characterization of both constitutional isomers was facilitated by ESI-MS, TWIM-MS, ${ }^{1} \mathrm{H}$ NMR and ${ }^{13} \mathrm{C}$ NMR. Of particular interest are the notably different drift times observed in the ion mobility separation that unequivocally demonstrated the different sizes and morphologies of the isomers at high charge states.

In an effort to examine the outcome(s) of reacting building blocks with differing geometries (Lu et al., 2012) we constructed two new bisterpyridine ligands $\mathbf{5 1}$ and $\mathbf{5 2}$ $\left(120^{\circ}\right.$ - and $60^{\circ}$-oriented, respectively). Reaction of these two building blocks with $\mathrm{Zn}\left(\mathrm{NO}_{3}\right)_{2} \cdot 6 \mathrm{H}_{2} \mathrm{O}$ in a precise $2: 1: 1$ ratio in $\mathrm{MeOH}$ for $30 \mathrm{~min}$ at $25^{\circ} \mathrm{C}$ afforded rhomboidal complex 53 (Figure 22). Analysis by ESI-MS revealed the presence of the triangular species 55, which can also be prepared in high yields by reaction of building block 52 with a metal. Performing the reaction under refluxing conditions for $24 \mathrm{~h}$ gave the same mixture. And, replacing $\mathrm{Zn}\left(\mathrm{NO}_{3}\right)_{2} \cdot 6 \mathrm{H}_{2} \mathrm{O}$ with $\mathrm{Cd}\left(\mathrm{NO}_{3}\right)_{2} \cdot 4 \mathrm{H}_{2} \mathrm{O}$ gave the $\mathrm{Cd}^{2+}$-based product mixture of rhombus and triangle, as revealed by ESI-MS.

To further probe the self-assembly a rhomboidal structures, tristerpyridine $\mathbf{4 3}$ was prepared; notably, it is a structural hybrid of both the $60^{\circ}$ - and $120^{\circ}$-based bisligands. Upon treatment of monomers 52 and $\mathbf{4 3}$ and $\mathrm{Zn}\left(\mathrm{NO}_{3}\right)_{2} \cdot 6 \mathrm{H}_{2} \mathrm{O}$ in a ratio of $2: 2: 5 \mathrm{in} \mathrm{MeOH}$ at $25^{\circ} \mathrm{C}$ for 30 min, followed by ion exchange with $\mathrm{NH}_{4} \mathrm{PF}_{6}$, a slightly yellow precipitate (i.e., rhombus 54) was obtained in $95 \%$ yield. Unequivocal characterization was obtained with 2D COSY and NOESY NMR, along with ESI-TWIM-MS, which showed the complete absence of the triangle-based by-products (i.e., 55). It is also worth noting that the $\mathrm{Zn}$ complex of $\mathbf{5 4}$ show remarkable stability in that it was observed to remain intact when subjected to MALDI-ToFMS analysis in the linear mode. Normally, only Ru-based constructs have survived these conditions.

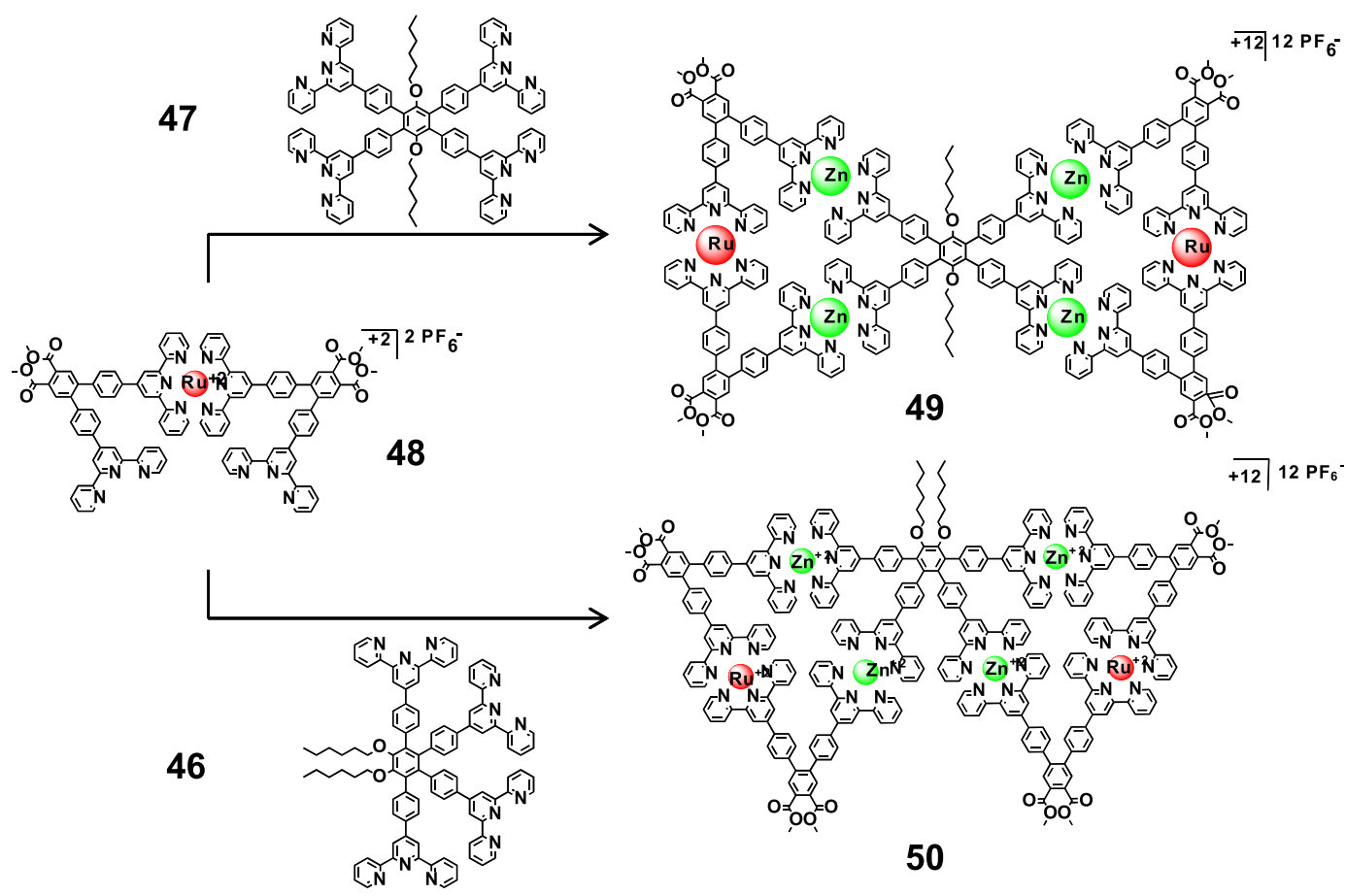

FIGURE 21 - Self-assembly of isomeric bowtie and butterfly bicyclic metallomacrocycles 49 and 50, respectively [Schultz, A.; Li, X.; Barkakaty, B.; Moorefield, C. N.; Wesdemiotis, C.; Newkome, G. R. J. Am. Chem. Soc., v.134, p.7672-7675, 2012.-1 Reproduced by permission of The American Chemical Society]. 


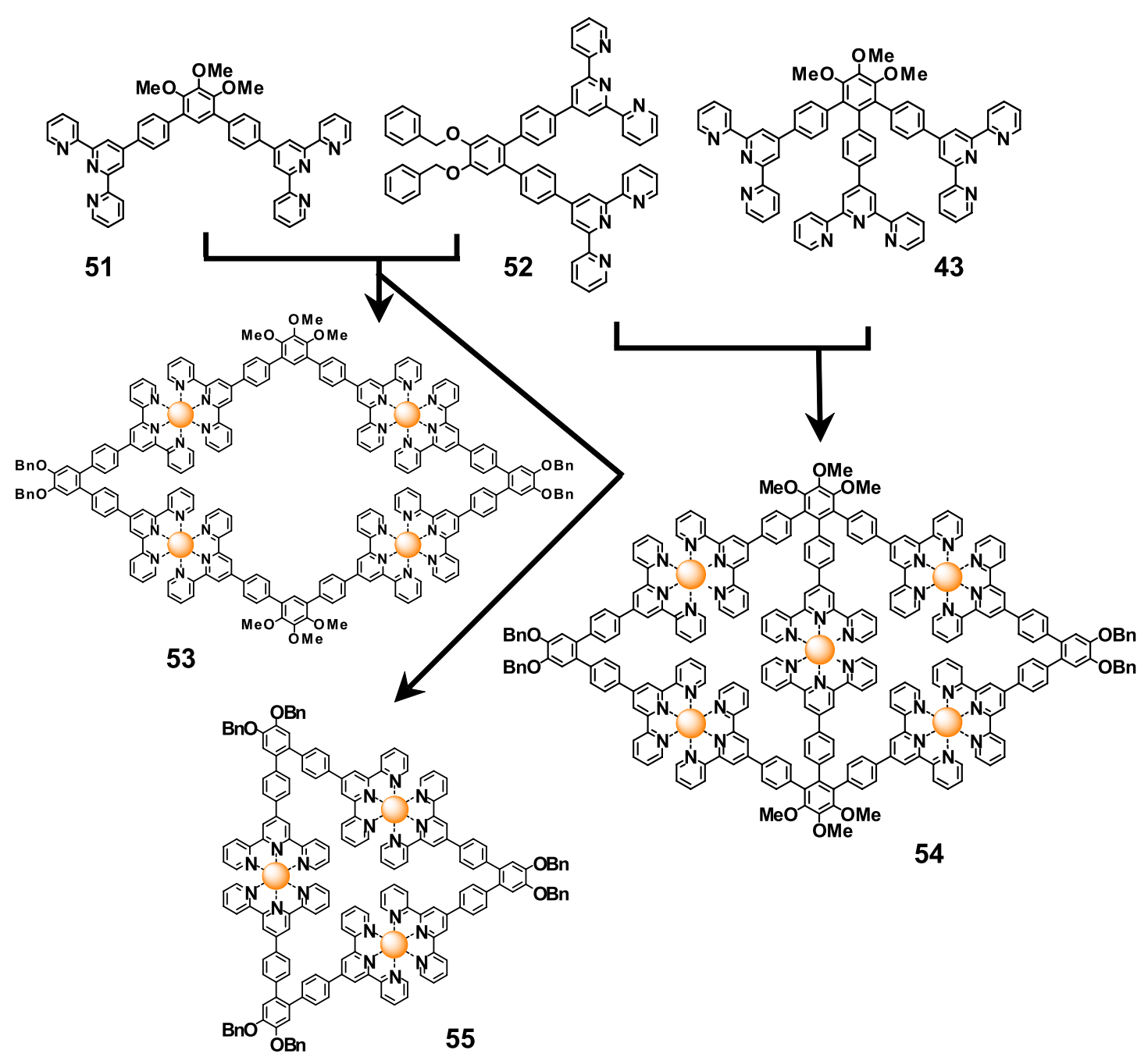

FIGURE 22 - Preparation of rhombohedral structures [Lu, X.; Li, X.; Wang, J.-L.; Moorefield, C. N.; Wesdemiotis, C.; Newkome, G. R. Chem. Commun., v.48, p.9873-9875, 2012. - Reproduced by permission of The Royal Society of Chemistry].

\section{CONCLUSIONS}

"Prediction is difficult, especially of the future" (Niels Bohr). The transformation of nature's chaos as seen in the eyes of mathematics to the design and construction of novel fractal macromolecular assemblies that can possess utilitarian applications in daily life is tomorrow's challenge.

\section{ACKNOWLEDGMENTS}

GRN would like to thank our numerous colleagues, who have assisted us and contributed to this growing fractal project over the years and are acknowledged on our publications. Support is also acknowledged from the U.S. Army Office of Research, Office of Naval Research, Air Force Office of Scientific Research, the National Science Foundation (DMR-86-00927, 89-06792, 92-17331, 96-
22609, 99-01393, 01-96231, 04-01780, ITM-04-14599, DMR-08-12337, DMR-07-05015, CHE-11-51991), initially Louisiana State University, the University of South Florida, and The University of Akron.

\section{REFERENCES}

BOISSELIER, E.; LIANG, L.; DALKO-CSIBA, M.; RUIZ, J.; ASTRUC, D. Interactions and Encapsulation of Vitamins C, $\mathrm{B}_{3}$, and $\mathrm{B}_{6}$ with Dendrimers in Water. Chem. Eur. J., v.16, p.6056-6068, 2010.

CHAN, Y.-T.; LI, X.; MOOREFIELD, C.N.; WESDEMIOTIS, C.; NEWKOME, G.R. Towards larger polygonal architectures: synthesis and characterization of iron(II)and $\mathrm{Ru}(\mathrm{II})$-Bisterpyridine metallomacrocycles. Chem. Eur. $J$. v.17, p.7750-7754, 2011a. 
CHAN, Y.-T.; LI, X.; SOLER, M.; WANG, J.-L.; WESDEMIOTIS, C.; NEWKOME, G.R. Self-Assembly and traveling wave ion mobility mass spectrometery analysis of hexacadium macrocycles. J. Am. Chem. Soc., v.131, p.16395-16397, 2009.

CHAN, Y.-T.; LI, X.; YU, J.; CARRI, G.A.; MOOREFIELD, C.N.; NEWKOME, G.R. Design, synthesis, and traveling wave ion mobility mass spectrometry characterization of Iron(II)- and Ruthenium(II)-Terpyridine macrocycles. $J$. Am. Chem. Soc., v.133, p.11967-11976, 2011 b.

CHAN, Y.-T.; MOOREFIELD, C.N.; SOLER, M.; NEWKOME, G.R. Unexpected isolation of a pentameric metallomacrocycle from an Fe(II)-Mediated complexation of $120^{\circ}$ juxtaposed 2,2':6',2"'-Terpyridine Ligands. Chem. Eur. J., v.16, p.1768-1771, 2010.

CHEN, X.; DING, Y.; CHENG, Y.; WANG, L. Synthesis, spectroscopy and electroluminescence of cadmium(II) polypyridyl complexes. Synth. Met., v.160, p.625-630, 2010.

CHENG, Y.; ZHAO, L.; LI, Y.; XU, T. Design of biocompatible dendrimers for cancer diagnosis and therapy: current status and future perrspectives. Chem. Soc. Rev., v.40, p.2673$2703,2011$.

CHO, T.J.; MOOREFIELD, C.N.; WANG, P.; NEWKOME, G.R. Metallodendrimers: fractals and photonics. ACS Symp. Ser., v.921, p.186-204, 2006.

FARIN, D.; AVNIR, D. Surface fractality of dendrimers. Angew. Chem. Int. Ed. Engl., v.30, p.1379-1380, 1991.

FRIEBE, C.; HAGER, M.D.; WINTER, A.; SCHUBERT, U.S. Metal-containing polymers via electropolymerization. $A d v$. Mater, v.24, p.332-345, 2012.

HALLÉ, F.; OLDEMAN, R.A.A.; TOMLINSON, P.B. Tropical trees and forests: an architectural analysis. Berlim: Ed. Springer, 1982. $441 \mathrm{p}$.

HARTMANN-THOMPSON, C.; KEELEY, D.L.; ROUSSEAU, J.R.; DVORNIC, P.R. Fluorescent dendritic polymers and nanostructured coatings for the detection of chemical warfare agents and other analytes. J. Polym. Sci. Part A: Polym. Chem., v.47, p.5101-5115, 2009.
HWANG, S.-H.; WANG, P.; MOOREFIELD, C.N.; GODÍNEZ, L.A.; MANRÍQUEZ, J.; BUSTOS, E.; NEWKOME, G.R. Design, self-assembly, and photophysical properties of pentameric metallomacrocycles: $\left[\mathrm{M}_{5}(N\right.$-hexyl[1,2bis(2,2':6',2"'-terpyridin-4-yl)]carbazole $\left.)_{5}\right][\mathrm{M}=\mathrm{Fe}(\mathrm{II})$, $\mathrm{Ru}(\mathrm{II})$, and $\mathrm{Zn}(\mathrm{II})]$. Chem. Commun., v.37, p.4672-4674, 2005.

KOO, B.W.; SONG, C.K.; KIM, C. CO gas sensor based on a conducting dendrimer. Sens. Actuators B, v.77, p.432-436, 2001.

KUMAR, A.; SUN, S.S.; LEES, A.J. Directed assembly metallocyclic supramolecular systems for molecular recognition and chemical sensing. Coord. Chem. Rev., v.252, p.922-939, 2008.

KUZDZAL, S.A.; MONNIG, C.A.; NEWKOME, G.R.; MOOREFIELD, C.N. Dendrimer electrokinetic capillary chromatography: unimolecular micellar behaviour of carboxylic acid terminated cascade macromolecules. $J$. Chem. Soc., Chem. Commun., p.2139-2140, 1994.

KUZDZAL, S.A.; MONNIG, C.A.; NEWKOME, G.R.; MOOREFIELD, C.N. A Study of Dendrimer-solute interactions via electrokinetic chromatography. J. Am. Chem. Soc., v.119, p.2255-2261, 1997.

LU, X.; LI, X.; WANG, J.-L.; MOOREFIELD, C.N.; WESDEMIOTIS, C.; NEWKOME, G.R. From supramolecular triangle to heteroleptic rhombus: a simple bridge can make a difference. Chem. Commun., v.48, p.9873-9875, 2012.

MANDELBROT, B.B. The fractal geometry of nature. New York: W.H. Freeman and Company, 1982.

MILLER, L.L.; KUNUGI, Y.; CANAVESI, A.; RIGAUT, S.; MOOREFIELD, C.N.; NEWKOME, G.R. "Vapoconductivity" sorption of organic vapors causes large increases in the conductivity of a dendrimer. Chem. Mater., v.10, p.1751-1754, 1998.

MOOREFIELD, C.N.; PERERA, S.; NEWKOME, G.R. Dendrimer chemistry: supramolecular prospectives and applications. Hoboken: John Wiley \& Sons, 2012. p.1-54.

NEWKOME, G.R.; BAKER, G.R. The chemistry of methanetricarboxylic esters: a review. Org. Prep. Proced. Int., v.18, p.117-144, 1986. 
NEWKOME, G.R.; BAKER, G.R.; ARAI, S.; SAUNDERS, M.J.; RUSSO, P.S.; THERIOT, K.J.; MOOREFIELD, C.N.; ROGERS, L.E.; MILLER, J.E.; LIEUX, T.R.; MURRAY, M.E.; PHILLIPS, B.; PASCAL, L. Synthesis and characterization of two-directional cascade molecules and formation of aqueous gels. J. Am. Chem. Soc., v.112, p.8458-8465, 1990.

NEWKOME, G.R.; BAKER, G.R.; SAUNDERS, M.J.; RUSSO, P.S.; GUPTA, V.K.; YAO, Z.; MILLER, J.E.; BOUILLION, K. Two-directional cascade molecules: synthesis and characterization of [9]-n-[9] arborols. $J$. Chem. Soc., Chem. Commun., p.752-753, 1986a.

NEWKOME, G.R.; CHO, T.J.; MOOREFIELD, C.N.; BAKER, G.R.; SAUNDERS, M.J.; CUSH, R.; RUSSO, P.S. Self- and direct-assembly of hexaruthenium macrocycles. Angew. Chem. Int. Ed., v.38, p.3717-3721, 1999.

NEWKOME, G.R.; MOOREFIELD, C.N.; BAKER, G.R.; JOHNSON, A.L.; BEHERA, R.K. Alkane cascade polymers possessing micellar topology: micellanoic acid derivatives. Angew. Chem., Int. Ed. Engl., v.30, p.1176-1178, 1991a.

NEWKOME, G.R.; MOOREFIELD, C.N.; BAKER, G.R.; SAUNDERS, M.J.; GROSSMAN, S.H. Unimolecular micelles. Angew. Chem., Int. Ed. Engl., v.30, p.1178-1180, $1991 b$.

NEWKOME, G.R.; MOOREFIELD, C.N.; KEITH, J.M.; BAKER, G.R.; ESCAMILLA, G.H. Chemistry within a unimolecular micelle precursor: boron superclusters by siteand depth-specific transformations of dendrimers. Angew. Chem., Int. Ed. Engl., v.33, p.666-668, 1994.

NEWKOME, G.R.; MOOREFIELD, C.N.; VÖGTLE, F. Dendrimers and dendrons: concepts, syntheses, applications. Weinheim: Wiley-VCH, 2001.

NEWKOME, G.R.; SHREINER, C.D. Dendrimers derived from 1 -> 3 branching motifs. Chem. Rev., v.110, p.6338$6442,2010$.

NEWKOME, G.R.; WANG, P.; MOOREFIELD, C.N.; CHO, T.J.; MOHAPATRA, P.; LI, S.; HWANG, S.-H.; LUKOYANOVA, O.; ECHEGOYEN, L.; PALAGALLO, J.A.; IANCU, V.; HLA, S.-W. Nanoassembly of a fractal polymer: a molecular "Sierpinski Hexagonal Gasket". Science, v.312, p.1782-1785, 2006.
NEWKOME, G.R.; WOOSLEY, B.D.; HE, E.; MOOREFIELD, C.N.; GÜTHER, R.; BAKER, G.R.; ESCAMILLA, G.H.; MERRILL, J.; LUFTMANN, H. Supramolecular chemistry of flexible, dendritic-based structures employing molecular recognition. Chem. Commun., p.2737-2738, 1996.

NEWKOME, G.R.; YAO, Z.; BAKER, G.R.; GUPTA, V.K. Cascade molecules: a new approach to micelles. A [27]-Arborol. J. Org. Chem., v.50, p.2003-2004, 1985.

NEWKOME, G.R.; YAO, Z.; BAKER, G.R.; GUPTA, V.K.; RUSSO, P.S.; SAUNDERS, M.J. Cascade molecules: synthesis and characterization of a Benzene[9] ${ }^{3}$-Arborol. J. Am. Chem. Soc., v.108, p.849-850, 1986b.

PARK, C.; IM, M.S.; LEE, S.; LIM, J.; KIM, C. Tunable fluorescent dendron-cyclodextrin nanotubes for hybridization with metal nanoparticles and their biosensory function. Angew. Chem. Int. Ed., v.47, p.9922-9926, 2009.

PEITGEN, H.-O.; JÜRGENS, H.; SAUPE, D. Chaos and fractals: new frontiers of science. New York: SpringerVerlag, 2004.

SCHUBERT, U.S.; HOFMEIER, H.; NEWKOME, G.R. Modern terpyridine chemistry. Weinheim: Wiley-VCH, 2006.

SCHULTZ, A.; CAO, Y.; HUANG, M.; CHENG, S.Z.D.; LI, X.; MOOREFIELD, C.N.; WESDEMIOTIS, C.; NEWKOME, G.R. Stable, trinuclear $\mathrm{Zn}(\mathrm{II})$ - and Cd(II)-metallocycles: TWIM-MS, photophysical properties, and nanofiber formation. Dalton Trans., v.41, p.11573-11575, 2012.

SCHULTZ, A.; LI, X.; BARKAKATY, B.; MOOREFIELD, C.N.; WESDEMIOTIS, C.; NEWKOME, G.R. Stoichiometric self-assembly of isomeric, shape-persistent, supramacromolecular bowtie and butterfly structures. J. Am. Chem. Soc., v.134, p.7672-7675, 2012a.

SCHULTZ, A.; LI, X.; MCCUSKER, J.K.; MOOREFIELD, C.N.; CASTELLANO, F.N.; WESDEMIOTIS, C.; NEWKOME, G.R. Dondorff rings: synthesis, isolation, and properties of $60^{\circ}$-directed bisterpyridine-based folded tetramers. Chem. Eur. J., v.18, p.11569-11572, 2012b.

TOMLINSON, P.B. Tree architecture. Am. Sci., v.71, p.141$149,1983$. 
WANG, J.-L.; LI, X.; LU, X.; HSIEH, I.-F.; CAO, Y.; MOOREFIELD, C.N.; WESDEMIOTIS, C.; CHENG, S.Z.D.; NEWKOME, G.R. Stiochiometric self-assembly of shape-pesistent 2D complexes: a facile route to a symmetric supramacromolecular spoked wheel. J. Am. Chem. Soc., v.133, p.11450-11453, 2011.

WANG, P.; MOOREFIELD, C.N.; JEONG, K.-U.; HWANG, S.H.; LI, S.; CHENG, S.Z.D.; NEWKOME, G.R. Dendrimermetallomacrocycle composites: nanofiber formation by multi-ion pairing. Adv. Mater., v.20, p.1381-1385, 2008.

WINTER, A.; HAGER, M.D.; NEWKOME, G.R.; SCHUBERT, U.S. The marriage of terpyridine and inorganic nanoparticles: synthetic aspects, characterization techniques, and potential applications. Adv. Mater, v.23, p.5728-5748, 2011 a.

WINTER, A.; NEWKOME, G.R.; SCHUBERT, U.S. Catalytic applications of terpyridines and their transition metal complexes. Chem. Cat. Chem., v.3, p.1384-1406, 2011 b.
YOON, Z.S.; CHAN, Y.-T.; LI, S.; NEWKOME, G.R.; GOODSON, T.G. III ultrafast time-resolved spectroscopy of self-assembled cyclic Fe(II)-Bisterpyridine complexes. J. Phys. Chem. B, v.114, p.11731-11736, 2010.

YOUNG, J.K.; BAKER, G.R.; NEWKOME, G.R.; MORRIS, K.F.; JOHNSON JR, C.S. 'Smart' cascade polymers. Modular syntheses of four-directional dendritic macromolecules with acidic, neutral, or basic terminal groups and the effect of $\mathrm{pH}$ changes on their hydrodynamic radii. Macromolecules, v.27, p.3464-3471, 1994.

YU, X.; YUE, K.; HSIEH, I.-F.; LI, Y.; DONG, X.-H.; LIU, C.; XIN, Y.; WANG, H.-F.; SHI, A.-C.; NEWKOME, G.R.; HO, R.-M.; CHEN E.-Q.; ZHANG, W.-B.; CHENG, S.Z.D. Giant surfactants provide a versatile platform for sub-10-nm nanostructure engineering. P. Natl. Acad. Sci. USA, v.110, p.10078-10083, 2013. 